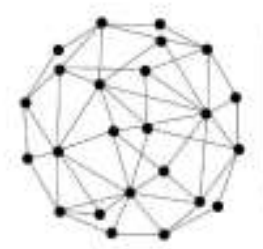

\title{
VISION ON THE QUALITY OF WEBSITES AND THEIR EFFECTS ON THE INTENTION OF USE AND RECOMMENDATION OF TOURISM SERVICES FOR DIFFERENT LEVELS OF CONSUMER EXPERIENCE
}

Lenita Morimura

Last degree: Bachelor of Business Administration from the Federal University of São Paulo Work area: ATM Supply Planning Analyst at TecBan - Tecnologia Bancária S.A. lenitamm@hotmail.com

Luis Hernan Contreras Pinochet

Post-doctorate in Business Administration from Universidade Nove de Julho Professor of the Academic Administration Department at the Federal University of São Paulo luis.hernan@unifesp.br

Evandro Luiz Lopes Associated Full Professor in Marketing from the Federal University of São Paulo (Universidade Federal de São Paulo) and Post-doctor in Marketing from the Federal University of Minas Gerais. Professor in the Postgraduate Program in Business Administration at the University Nove de Julho and Professor at the Academic Department of Administration - Federal University of São Paulo. elldijo@uol.com.br

$\mathrm{PhD}$ student in Business Administration at Universidade Nove de Julho and Master in Business Administration at Faculdades Metropolitanas Unidas. Public servant at the city hall of São Paulo, language reviewer. liaherrero@gmail.com

Miriam Christi Midori Oishi Nemoto $\mathrm{PhD}$ in Business Administration from the Faculty of Administration, Economics and Accounting at the University of São Paulo. Professor at the Academic Department of Business Administration at the Federal University of São Paulo. miriam.oishi@unifesp.br

Purpose: The expansion of e-commerce contributes a considerable portion to the revenues of large companies in the tourism sector. Modern companies must employ web-based tools, offering the best experience to users, in order to satisfy their consumers and boost their business. Therefore, with this study, we seek to analyze the factors that contribute to ratings of quality for websites for online tourism services in terms of the intention to use and to recommend for different levels of consumer experience.

Method: The survey was a sample of 437 valid questionnaires, using a structured collection instrument with 22 assertions on a Likert scale, based on the WEBQUAL 4.0 scale, and two assertions based on the proposed scale for the Net Promoter Score (NPS). The models used were Reichheld and Markey (2012) and Ahmad and Khan (2017).

Results: As a result, we verified that a predominance of users employs online tourism services infrequently, which allowed us to establish a differentiation between two groups: Low Experience and High Experience.

Theoretical contributions: The study indicates that for those who use the sites more frequently, the considered variables (ease, information, safety) have no effect on loyalty and recommendation. Among the less frequent users, information is important, and safety has little effect on the recommendation. Therefore, we found that the respondents of this research study do not consider ease of use as a premise for the continuity of use or recommendation of online tourism services, regardless of their previous level of experience.

Managerial contributions: Identifying the antecedents of the intention to use online services in the tourism consumption process makes it possible for managers to improve actions on digital platforms. This is a way to encourage users to execute commercial transactions.

Social contributions: Low relevance for website security is an issue that arises from the results obtained in this study. Although this phenomenon can partially be explained by the (low) age of the respondents, there is an opportunity for regulatory and consumer protection agencies to take measures to ensure that the minimum safety requirements are present in online tour operators.

Keywords: Tourism. E-commerce. Quality. Intent to continue using. Intention to recommend.

\section{How to cite the article}

American Psychological Association (APA)

Morimura, L., Pinochet, L. H. C., Lopes, E. L., Herrero, E., \& Nemoto, M. C. M. O. (2020). A vision on the quality of websites and their effects on the intention of use and recommendation of tourism services for different levels of consumer experience. Brazilian Journal of Marketing, 19(2), 261-286. https://doi.org/10.5585/remark.v19i2.16118. 


\section{Introduction}

Modern tourism represents an important source of internal income for many countries (UNWTO, 2018), contributing to the creation of jobs, improvements in infrastructure, and quality of life (Cárdenas-García, Sánchez-Rivero, \& Pulido-Fernández, 2015). Tourism is also linked to the development of destinations, through the improvement of the quality and infrastructure of places. Given its character, tourism is synonymous with growth for other interrelated industries, such as the service industry, as it caters to various classes of people.

In 2018, the tourism sector showed a continuous growth, achieving the highest growth of $7 \%$ the last year (UNWTO, 2018), overcoming the previous seven years that grew around $4 \%$ and is the third fastest growing sector in the world. In addition, tourism account represents $10.4 \%$ of the world's Gross Domestic Product (GDP), with 1.3 billion international tourists, and a projected 1.8 billion by 2030 . Tourism is the third large export category, reaching US\$ 1.3 trillion. In Brazil, in 2017, the direct contribution of the tourism sector represented US\$ 59.6 billion, or $2.9 \%$ of the total GDP, with a forecast to rise by $2.5 \%$ in 2018 . The indirect contribution represented US\$ 163.0 billion (7.9\% of the Brazilian GDP), according to the World Travel \& Tourism Council's annual report (WTTC, 2018).

In the tourism sector, as well as in other sectors, the expansion of e-commerce accounts for a considerable portion of the revenues of large retailers. Brazil, with 120 million online users in 2015 , is the fourth largest country with respect to absolute number of tourists, behind only the United States, India, and China (UNCTAD, 2017).

According to the Ministry of Tourism (BRASIL, 2018), the growing initiative in relation to the search and comparisons among ticket prices, accommodations, and means of transportation provided by websites make the online tourism service a profitable segment for e-commerce. The data from the Consumer Survey - Intent of Travel (BRASIL, 2018), shows that Brazilian's intention to travel reached 24.3\% until March 2019.

This virtual revolution has caused changes in tourism agencies, since even those that have physical stores also create shopping options through virtual tools (Park, Campbell, \& Kwak, 2012). Although technology still does not replace certain aspects of human interaction, such as courtesy, sympathy, utility, care, commitment, and flexibility, companies must employ web-based tools to deliver the best user experience and satisfy their consumers (Ahmad, Rahman, \& Khan, 2016). The quality of the site plays an important role in the form and communication of the image, as a background of cultural differences (Deng \& Poole, 2012). 
The quality in the electronic service also presents potential in strategic terms, contributing, consequently, to the profitability of the company (Zeithaml, 2002; Cronin, 2003).

Overall, researchers are interested in investigating online consumer behavior (Ahmad \& Khan, 2015; Ahmad, Rahman \& Khan, 2016), including those who use tourism services. Researchers such as Ferguson, Megehee, and Woodside (2017) try to explain the behavior of these users from three perspectives: a) profile of the consumer, b) their use of the Internet, and c) their attitudes towards online shopping.

In addition to the quality of the websites, this article seeks to establish the relationship between these three constructs and consumer behavior, regarding the continuity of service use and the intention to recommend the service to third parties ( Reichheld \& Markey, 2012).

The potential contribution of the article is the comparison of effects between frequent and infrequent users. Thus, the objective was to analyze the antecedent factors of quality in websites that contribute to online tourism services with respect to the consumer's intention to continue to use and to recommend the service, given different levels of consumer experience. We understand that, given the growth of the tourism market, combined with the emergence of several digital platforms in the segment, a study that identifies the antecedent factors of the declaration of intention to use online tools in this scenario is relevant.

This study is structured in four other sections, in addition to this brief introduction. The theoretical framework that supports the construction of the theoretical model and the hypotheses that were tested in the empirical phase of the study is presented. The third section presents the method that guided the empirical phase of the study and, in the following section, the results are presented. Finally, the last section presents the conclusions and final considerations.

\section{Theoretical foundation}

In this section, the addressed topics e-commerce, website quality, consumer behavior, and tourism give theoretical support to this studied.

\subsection{E-commerce}

E-commerce is an Internet market in which buying and selling transactions are carried out, in a similar manner to traditional markets. However, in e-commerce, the user is able to choose, book, buy, and have requests answered at home (UNWTO, 2018), since the transaction is done online. Electronic commerce may also be defined as the exchange of 
products, services, goods, and ideas or communications by electronic means for the purpose of facilitating or conducting business, and may involve the requesting, payment, and effective delivery of goods or services.

The adoption and use of e-commerce in the tourism sector has created opportunities for the introduction of business practices, by the capacity to reduce costs and improve productivity, which favor growth. Therefore, tourism companies that use IT innovations strengthen their competitive advantage.

The importance of the Internet and e-commerce in tourism is highlighted by Werthner and Ricci (2004), who point out that e-commerce can generate revenue growth in the sector. The success comes from the complementarity of the two segments, because the tourism sector is an area of intensive information, and e-commerce and the Internet can influence the experience and increase tourism. Consumers have also become increasingly powerful, sophisticated, and experienced and are able to determine the elements that make up their tourism products. Thus, intense competition among travel websites requires companies to understand how their users compare sites (Mohd, Winklhofer, \& Ennew, 2014). E-commerce allows information to flow worldwide, with virtually no entry barriers, allowing a space where tourists can access the information they need, customize their trips, and have the option to make purchases (Kourtit et al., 2011; Munar \& Jacobsen, 2014).

\subsection{Quality of websites and evaluation models}

Quality of websites is a prerequisite for effective digital marketing. However, its process is complex and full of multidimensional measurement criteria. Quality measurement can be represented by a model consisting of three factors: information quality, system quality, and service quality (DeLone \& McLean, 2003). Lee and Kozar (2006) affirm that the quality of information is the first visible indicator of a site and refers to the communication produced and made available, as evaluated by the user. Therefore, the information must be relevant, complete, and easy to understand.

In order to verify the quality of the system, it is necessary to measure the personalization, the navigability, and the security of the software and the site itself. Personalization is integrated as an individualized interface, with targeted information and adequate services for each user (Lee \& Kozar, 2006). Navigability is presented with structured menus, with links to the home page, standard web pages, and search tools 
(Schmidt, Cantallops \& Santos, 2008). Finally, security corresponds to high levels of privacy for online transactions (Zeithaml, Parasuraman, \& Malhotra, 2002). Quality of service influences user loyalty and is fundamental to the company's success (Lin, Chan, \& Tsai, 2009). Thus, it is necessary to detect failures in service delivery. In addition, online users prefer sites that have an easy-to-use interface, useful links, and fast connections, regardless of whether they are looking for information or wanting to book reservations (Ho \& Lee, 2007).

The evaluation of quality in the marketing area derives from works developed since 1985 by Parasuraman, Zeithaml, and Berry, authors who developed the SERVQUAL model, which evaluates, by dimensions, the differential between customer expectations and the service rendered. In the 1990s, SERVPERF was developed (Jain \& Gupta, 2004; Conger et al., 2012), a simplification of the SERVQUAL model, with a reduction in the number of questions and their subjectivity. The first application of such a model on the websites was called e-SERVQUAL and was developed by Zeithaml, Parasuraman, and Malhotra (2000).

Also, in 2000, Barnes and Vidgen presented the model WEBQUAL. The primary indicator consisted of the usefulness of the website, taking into account the user's perception and interaction. Later, the authors presented the WEBQUAL model, analyzing the quality of the online transaction as a reflection of the quality of the service provided (Barnes \& Vidgen, 2002). Although based on users' subjective impressions, the data collected in the model allows a quantitative analysis and elaboration of e-commerce metrics.

Subsequently, WEBQUAL 2.0 was created, with a completed initial column, without, however, simultaneously associating the two subjects (quality of transaction and service rendered). In WEBQUAL 3.0, three topics were defined: website quality, information quality, and interaction quality. This model was replaced by WEBQUAL 4.0, after failures were addressed and usability, understood as ease of use, was increased. The quality of the software was also improved so that the focus was not restricted to the design and the software, but to verify the perceptions of user.

Thus, with the evolution of e-commerce, the correct measurement of users' interactions with companies in websites is a critical element in the overall evaluation of the quality of service by the client. In the case of tourism services, global competition and the need to reduce costs make e-commerce a very relevant channel, and there are companies that only operate in this way. 


\subsection{Consumer Behavior}

Consumer behavior is described as the mental, emotional, and psychological activity that people use during the selection, purchase, use, and post-purchase of products and/or services that meet their needs and desires. The consumer buying decision is highly influenced by four characteristics: cultural, social, personal, and psychological factors (Ferguson, Megehee, \& Woodside, 2017). Although these factors are uncontrollable, they must be considered in order to understand the behavior.

Consumption in the tourism industry is strongly influenced by the optimism and confidence of people living in countries with economic growth, employment, and peace (Lee, 2013). In this context, the tourism consumer has become intensely participatory, seeking information on benefits, prices, experience reports, evaluations on products, and services. In addition, by accessing the internet, tourist consumers can check offers that they want and that are in agreement with what they are willing to pay, searching websites of suppliers, search sites, price comparison sites, or social networks.

\section{Model and Hypotheses}

The present research is dedicated to the analysis of website factors that contribute to the quality and use of online tourism services that influence the intention to continue using and the intention to recommend. The scales used for this purpose are presented in Appendix A.

In this article, we intended to determine the factors for online tourism service sites that increase quality. Thus, we elaborate hypotheses that test the influence of each dimension of the WEBQUAL 4.0 model, created by Barnes and Vidgen (2002), and the model of "The definitive question," determined by Reichheld and Markey (2012), as originated in the previous study of Reichheld (2003): Net Promoter Score (NPS). In short, the hypotheses test the influence of perceived quality on consumer behavior regarding the intention to continue using or recommending online tourism service sites.

"The definitive question" proposed by Reichheld and Markey (2012) is the one that presented the highest degree of correlation to the expected behavior of a loyal consumer: "What is the probability that you will recommend us (the company) to a friend?" However, it is noted that there are conditions to be satisfied for consumers before they will recommend or indicate the company in their social circles in a positive way. First, the customer needs to 
believe that the organization offers superior values in terms of functionality, ease of use, quality, physical characteristics, price, or other factors that can to some extent be expressed in economic terms. In addition, the relationship that consumers have with the company should make them feel good, that is, the users must believe that the company knows, understands, and hears their personal values and shares the same principles. Therefore, the customers must want to continue to use the product and/or service so that they can then recommend.

The construct Information of the model WEBQUAL conditions the different profiles of users, who perceive the quality of the information produced and made available (Lee \& Kozar, 2006), being the first visible indicator of a website (DeLone \& McLean, 2003). The next hypotheses of the research are thus observed:

H1a: Information positively influences the intention to recommend online tourism services. H1b: Information positively influences the intention to continue using online tourism services.

The Service Interaction of the WEBQUAL model covers the different user profiles, for which the interaction of the service is considered by the accessibility, speed, and capacity of the information search (Madu \& Madu, 2002). Security is important to the user, providing high levels of privacy for online transactions (Zeithaml, Parasuraman, \& Malhotra, 2002). Website security protects information in transactions against potential third-party threats (Chu, 2001). The final hypotheses of the research are thus formulated:

H2a: Service interaction positively influences the intention to recommend online tourism services.

H2b: Service interaction positively influences the intention to continue using online tourism services.

The Usability construct of the WEBQUAL model conditions the different user profiles. In this dimension, the perception of the quality of the websites of the online tourism service is directly related to the experience of using and perceiving self-efficacy (Yoo \& Donthu, 2001). A good website performance provides greater convenience, privacy, and rapid response (Ahn, Ryu \& Han, 2007). Thus, the first hypotheses of the research are formulated:

H3a: Usability positively influences the intention to recommend online tourism services. H3b: Usability positively influences the intention to continue using online tourism services. 


\section{Method}

This study is characterized as a quantitative cross-sectional approach (Malhotra, 2014), with data collection performed from September 11 to 31, 2017, through a survey, replicating and adapting the study of models by Reichheld and Markey (2012) and Ahmad and Khan (2017) for the Brazilian reality. For this adaptation, we used the reverse translation process, and before the application, we submitted the questionnaire to a checking for understanding pre-test, conducted with 25 subjects.

The questionnaire was based on divided theoretical aspects and grouped in constructs, which deal with the same aspect. We collected data through e-mail lists, with online survey QuestionPro and the online environment, using the social networks: Facebook and WhatsApp, as they play an important role in creating trust (or mistrust) for a particular brand or company. Customer-to-customer conversations that occur on these platforms are increasingly informing the attitudes, beliefs, and confidence levels towards companies (Munar \& Jacobsen, 2013).

The individuals were selected for convenience and characterized as a group present in social networks and concentrated in São Paulo city. The data were collected through a structured questionnaire, with a five-point Likert scale, ranging from (1) "totally disagree" to (5) "strongly agree." There was also a second block of questions to collect demographic information and to assess other issues related to the use of online tourism services, aiming to establish the profile of the respondents.

Data were purified for analysis, and outliers were eliminated. The process of purification of the database was finalized with the withdrawal of 121 (29 whose respondents did not answer more than $10 \%$ of the questionnaires and 92 whose respondents used only one or two points of the Likert scale in all responses), leaving a total of 437 observations.

Exploratory Factorial Analysis (EFA) and Structural Equation Modeling (SEM) allowed the verification of adjustments between observed data and the theoretical model specified a priori. To identify the profile of the sample, descriptive statistics were used. The EFA was performed with the support of the IBM SPSS 22 software and the Modeling of Structural Equations, conducted through partial least square (PLS) analysis (Chin, 1988), was performed with the use of SmartPLS 3.0 software.

In tourism research the use of PLS-SEM is common, since the logic used is a more comprehensive review, allowing a more effective evaluation of the context of the research and its use is increasing in business and tourism research. PLS-SEM is an alternative technique to the traditional CB-SEM, since it offers greater flexibility to data assumptions, sample size, 
and complex model analysis, due to its "reflective" constructions and to enable predictiverelation tests among constructs. These characteristics make PLS-SEM particularly useful for tourism researchers making it our best research tool (Do Valle \& Assaker, 2015).

\section{Data Analysis}

The objective of this section is to present the results of the analysis of the empirical data, which involved descriptive, exploratory, and multivariate factorial analyses.

\subsection{Characteristics of respondents and use of online tourism services}

For demographic analysis of respondents of this research, we found that, among men $(41.19 \% ; \mathrm{n}=180)$ and women $(52.40 \% ; \mathrm{n}=229)$, more than half $(52.17 \% ; \mathrm{n}=228)$ are 25 years of age or younger. The majority $(94.73 \%, \mathrm{n}=204)$ are enrolled in undergraduate courses, $38.7 \%(\mathrm{n}=146)$ have a family income between $\mathrm{R} \$ 4,852.00$ and $\mathrm{R} \$ 9,254.00$ (1 R $\$=\mathrm{US} \$ .26$ ).

Users indicated low frequency of use of online tourism services, and 53\% $(\mathrm{n}=213)$ endorsed the "Once a year or less" option and 31.3\% $(\mathrm{n}=126)$ indicated "Twice a year" (31.3\%, $\mathrm{n}=126)$. Approximately $85 \%$ of the respondents hired some tourism service. It is observed that the frequency of use is not directly proportional to the contracting of services.

Moreover, the same users who are low frequency users are those that hire services in order to spend holidays $(46.27 \%, \mathrm{n}=186$, for those marked "Once a year or less", and $26.87 \%$, $\mathrm{n}=108$, for those who indicated "Twice a year") in their travel destinations.

It was possible to verify the predominance of loose purchases. A loose purchase is a purchase made directly from the airlines, hotels, or entertainment service sites. These purchases account for more than half of the responses $(53.50 \%, \mathrm{n}=204)$, as opposed to direct purchases from online service agencies, single or package $(44.70 \%, \mathrm{n}=178)$.

Among the respondents, the low frequency of use of online tourism services is predominant for all types of transactions: booking a flight, booking accommodations, buying a tour package, and renting a car, among others.

Regarding the evaluation of online tourism services, among the sites that were listed, $80 \%$ were never used by more than $50 \%$ of the respondents. Only Gol, Latam and Decolar.com websites were identified by more than $50 \%$ of respondents. In addition, only Decolar.com was classified as very good $(20.40 \%)$, and it was not possible to establish a parameter of comparison between sites. 


\subsection{First Multivariate Phase: Exploratory Factor Analysis (EFA)}

After analyzing the answers of the questionnaires, we verified that the question that best explains the results of the sample was: "How often do you use the following online tourism services: booking a flight, booking accommodations, buying a tour package, and renting car," with anchors of 1 - not frequent and, 7 - too often. From this question, a measurement variable was created to indicate the frequency of use of tourism services on websites in relation to flights, accommodations, packages, and cars.

In this sense, an EFA was performed with these four variables, in which the interest was mainly centered on the common factors, which are interpreted in relation to the observed variables (Hair et al., 2014). The first analysis took place through the matrix of commonalities. In the first iteration, the variable freq_pack indicated .427, and was thus discarded. When a new EFA was performed, all commonalities presented values higher than $.5\left(\mathrm{~h}_{\text {freq_flight }}^{2}=.769 ; \mathrm{h}_{\text {freq_accom }}^{2}=.721 ; \mathrm{h}_{\text {freq_car }}^{2}=.616\right)$.

For this analysis, we used the Kaiser-Meyer-Olkin (KMO) criterion and Bartlett's Sphericity Test (Dziuban \& Shirkey, 1974). In this case, we verified that the $\mathrm{KMO}=.680$, which presents an adequate result. In the case of the Bartlett sphericity test, the result was significant, with $\mathrm{p}<.001$. After these procedures, we observed the cross-factor load and some variables were excluded. The unidimensionality score (score $>.50$ in the factor) and the low cross load score (score $<.40$ in the other factors) were observed (Levin, Fox \& Forde, 2013). All variables had adjustments due to commonality (h2<.5) and weak coefficients (<.4). In the end, the loads were adjusted to a factor with three items, which explained $79.19 \%$ of the total variance of the sample $(\alpha=$.787). The AFE resulted in the extraction of only one component, called Experiment (freq_flight, freq_accom, and freq_car). The measurement variable was constructed based on the average of the Experience $(\bar{x}=3.16)$, being subdivided into two groups: Low Experience and High Experience. The Low Experience group consisted of 228 individuals, representing $52.2 \%$ ( $\bar{x}=1.81)$ of the sample, and the High Experience group was formed by 209 individuals, representing $47.8 \%\left(\bar{x}=4.82 ; \mathrm{t}_{(411)}=30.55, \mathrm{p}<.01\right)$.

The differentiation of the two groups is due to the frequency of use of online tourism services on websites, in which the group called Low Experience corresponds to those respondents who use them with low frequency and therefore have less experience. On the other hand, the other group, called High Experience, corresponds to those users who use the services with high frequency. 


\subsection{Second Multivariate Phase: Estimation and Modeling of Structural Equations}

The normality of the data was verified by means of the non-parametric test Komolgorov-Smirnov. All the individual p-values of the K-S test, referring to the indicators, were significant, with $\mathrm{p}<.01$. Regarding the dependent variables Intention to Recommend and Intention to Continue Using, the absence of multicollinearity of the data was identified, since all the values of the variance inflation factor (VIFs) were below 5 .

After establishing the two groups to be studied (High Experience and Low Experience), with the indicated measurement variable (Experiment), the construction of path diagrams of established relationships was created, allowing the visualization of relationships derived from constructs.

Initially, the measurement model was evaluated, and adjustments were necessary, with the withdrawal of items that had low factor loads. This reasoning is illustrated by Pett, Lackey, and Sullivan's (2003) argument about the development of a scale that involves interests more directed to the constructs than to the items used to measure them.

The analysis of the measurement model must precede the analysis of the relationships between the latent variables. Thus, the next step was to examine the mean variances extracted (AVE) and convergent validity, discriminant validity, quadratic correlations between constructs, and composite reliability. In the first iteration, items SI4=.452 and SI5 $=.110$ were removed. Then, in the adjustment of AVE, items US5 = .519; IN5 = .612; SI6 = .552; US6 = .533 ; and, finally, the item IN7 $=.651$, for the Convergent Validity adjustment.

However, when performing the Discriminant Validity analysis, we observed that the Usability and Service Interaction constructs presented excessive correlations, being necessary to exclude items US7 $=.637$; SI1 $=.725$ and US8 $=.644$, for model adjustment. The items of the scales went through a reverse translation process and were validated in the exploratory phase of the factor analysis. Thus, there is no theoretical problem in the construction of the original scales; their dismissal was due to the rigor in conducting the statistical analysis that, as stated by Simon (2001), should result in some elimination.

Since all the variables of a questionnaire use the same measurement scale, the coefficient is calculated from the variance of the individual items. Cronbach's Alphas ranged from .711 to 1.00 , with values between .60 and .75 being considered moderate, and from .75 to .90 , high (Malhotra, 2014). The composite reliabilities ranged from .837 to 1.00 and were considered adequate. Thus, in the model proposed here, the results of the factorial loads 
obtained by each of the constructs are presented, observing the values of the factorial loads of each of the variables, which presented values above .5 (Figure 1).

In this study, the AVEs ranged between .516 and 1. For this analysis, the criteria of Fornell and Larcker (1981) were used, which dictate that AVE values should be higher than .5. In this sense, all the latent variables presented mean variance extracted greater than $50 \%$, which meets the criteria of Chin (1988) and Hair et al. (2010) to indicate the existence of convergent validity. Also, $\mathrm{R}^{2}$ demonstrated that the model has accuracy and predictive relevance in relation to the construct Intention to Continue Using (.105) and Intention to Recommend (.152). Even though the indicators did not present high overall scores, we agree with Kvålseth (1985) that $\mathrm{R}^{2}$ should be considered as an indicator of quality of fit and not an absolute and definitive indicator of the regressive model. The final indicators are presented in Table 1.

Table 1 - Discriminant validity

\begin{tabular}{lcrrrr}
\hline & $\mathbf{1}$ & $\mathbf{2}$ & $\mathbf{3}$ & $\mathbf{4}$ & $\mathbf{5}$ \\
\hline 1- Information & $\mathbf{. 7 1 8}$ & & & & \\
2- Intention to Continue Using & .312 & $\mathbf{1 . 0 0 0}$ & & & \\
3- Intention to Recommend & .361 & .813 & $\mathbf{1 . 0 0 0}$ & & \\
4- Service Interaction & .685 & .278 & .355 & $\mathbf{. 7 9 4}$ & \\
5- Usabilility & .713 & .234 & .279 & .590 & $\mathbf{. 8 4 9}$ \\
\hline
\end{tabular}

Note: The highlighted diagonal shows the square roots of the AVE.

Source: Research data.

The general adjustment indicators demonstrate the suitability of the final model, as seen in Table 2.

Table 2 - Indicators of convergent validity

\begin{tabular}{lcccc}
\hline & $\begin{array}{c}\text { Cronbach's } \\
\text { Alpha } \\
>.7\end{array}$ & $\begin{array}{c}\text { Composite } \\
\text { reliability } \\
>.7\end{array}$ & $\begin{array}{c}\text { Average } \\
\text { Extracted } \\
\text { Variance } \\
\text { (AVE) } \\
>.5\end{array}$ & $\mathbf{R}^{\mathbf{2}}$ \\
\hline Information & .768 & .842 & .516 & \\
Intention to Continue Using & 1.000 & 1.000 & 1.000 & .105 \\
Intention to recommend & 1.000 & 1.000 & 1.000 & .152 \\
Service Interaction & .711 & .837 & .631 & \\
Usability & .871 & .911 & .721 & \\
\hline Source: & & &
\end{tabular}

Source: Research data. 
The measurement theory specifies how the constructs are measured. The measurement scale of the Modeling of Structural Equations used in this work is reflective, thus, the direction of causality is from the latent variable of the indicators (Hair et al., 2014).

Figure 1 - Proposed Model

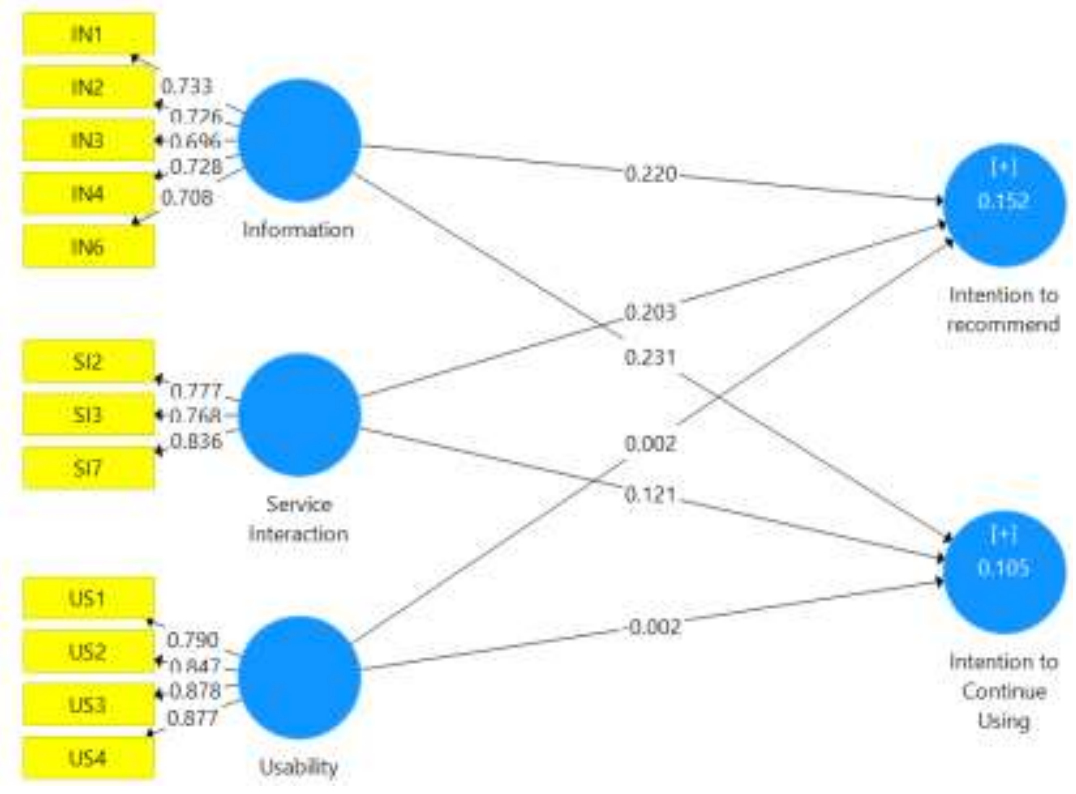

Source: The authors.

In the practical application of the Modeling of Structural Equations for the proposed model, the approach suggests the evaluation of the individual measurement models, seeking to verify their validity and consistency, and then to approach the structural model. Thus, other samples composed of elements of the original sample are developed and the parameters of the model are estimated (Hair et al., 2010).

The model proposed in this research was estimated using the bootstrapping technique, comparing the original sample with the samples generated by this technique. In this sense, another 500 samples were generated and the Student $t$ test was performed. These values are interpreted in Table 3. 
Table 3 - Analysis of the significance of the paths

\begin{tabular}{lccccc}
\hline Hypotheses and Paths & $(\boldsymbol{\beta})$ & Bootstrapping & SE & Statistic t & Sig. \\
\hline H1a: Information -> Intention of Continue Using & .231 & .237 & .066 & 3.506 & $*$ \\
H1b: Information -> Intention to Recommend & .220 & .226 & .068 & 3.236 & $* *$ \\
H2a: Service Interaction -> Intention of Continue Using & .121 & .125 & .064 & 1.900 & $* * *$ \\
H2b: Service Interaction-> Intention to Recommend & .203 & .203 & .066 & 3.089 & $* *$ \\
H3a: Usability -> Intention to Continue Using & -.002 & -.056 & .043 & .051 & N.S. \\
H3b: Usability -> Intention to Recommend & .002 & .055 & .041 & .046 & N.S. \\
\hline
\end{tabular}

Notes: $* \mathrm{p}<.001, * * \mathrm{p}<.05 * * * \mathrm{p}<.10$. N.S. $=$ not significant

Source: Research data.

Thus, the results show that the hypotheses $\mathrm{H} 1 \mathrm{a}$ and $\mathrm{H} 1 \mathrm{~b}$ indicate that the user demonstrates concern about the information when using the online tourism service sites. Such concerns relate to site accuracy, reliability, degree of relevance, appropriate level of detail, and the emergence at the exact moment of need, changing only the degree of significance. In $\mathrm{H} 1 \mathrm{a}$, the causal relationship of the path Information and Intention to Continue Using with $\beta=$ .261 was significant, presenting the first largest t-test $=3.506$. In $\mathrm{H} 1 \mathrm{~b}$, there was the causal relation of the path Information and Intention to Recommend, with $\beta=.220$ and test $t=3.236$, the second largest of all hypotheses.

Possibly, the respondents of this research are users that seek information about the place they will visit, needing more information before the trip to plan the activities they will carry out in their destinations, thus obtaining more independent, free travel without the need to get the information they need. The information contained in the sites becomes very important, because, through its quality, the users come to have confidence in the site. Trust is an essential factor in e-commerce as well as the understanding of its drivers and results. First, its drivers allow us to know the relative importance of the aspects that influence it. Understanding these variables is essential for developing confidence-building measures. Second, their results allow us to better understand the importance of trust and its influence on online shopping behavior. Numerous studies have attempted to examine trust as a critical determinant of consumer intentions to purchase in e-commerce (Hsu, Chuang, \& Cheng-Se, 2014; Agag, \& El-Masry, 2016). However, little attention was given to trust in online travel websites or whether trust would have any effect on the behavior of their clients (Ayeh, Au, \& Law, 2013b; Filieri, 2015). 
It is fundamental that the sites offer, above all, accurate information, since tourism is intangible, heterogeneous and, unlike other tangible and homogeneous products, cannot be tested before purchase. Thus, any failure may cause the sale to not take effect.

Another determining factor, which differentiates e-commerce buying from traditional retail stores, is the ease of price comparisons and similar products, making it easy to change your site. In addition, users take time to search online and search for products and/or services that have value. It is necessary that the information is clear, objective, and precise so that it arouses the motivation of the user to remain navigating.

Regarding H2a, the causal relationship of the pathway Service Interaction and Intention to Continue Using, with $\beta=.121$ and test $t=1.900$, indicated low significance. This indicates that the user cares less about the security and delivery of the product/service, according to what was contracted.

As for $\mathrm{H} 2 \mathrm{~b}$, the causal relationship of the Service Interaction Path and Intention to Recommend had $\beta=.203$ and test $t=3.089$, the third highest among all hypotheses. This indicates that the user expresses concern about the safety and delivery of the product/service, according to the contractor, before they can recommend them to others, unlike the result of the intention to continue for their own use.

The respondents of this research, possibly, are part of the denominated new consumers of online tourism. These consumers are increasingly sophisticated and less interested in opting for standardized tourist packages, which leads to the favor of personalized tourism (Buhalis \& Law, 2008). They are also more demanding and seek a direct interaction with the supplier, in order to satisfy their specific desires and expectations. Users in this industry have a wide variety of tools to organize their travels, such as online travel agencies, search engines, social networks, portals, price comparison sites, collective purchasing sites, individual vendors, and intermediary sites. All these tools allow the best interactions that suit the consumers (Buhalis, 1998; Kim, Chung, \& Lee, 2011; Amaro \& Duarte, 2015).

The availability of product information in a virtual environment, as well as the didactic description of all stages of purchase, contributes to consumer confidence as well as the precise description of a product/service, as buyers know exactly what and when they will receive (Wolfinbarger \& Gilly, 2003).

As noted, security still presents itself as a factor of concern for users, due to the increase in network fraud, the impossibility of trying the products, and the lack of guarantees. After all, in shopping at e-commerce, it is necessary to provide information, such as credit 
card details, address, phone, and date of birth, and often the product/service is not purchased as expected. In the case of tourism, there is also no possibility of a return. However, in general, there is currently a better knowledge of providers, reinforced security measures and increasingly sophisticated strategies, not negatively influencing their intention to continue to buy customized products and services (Gretzel, Hwang \& Fesenmaier, 2012).

Both $\mathrm{H} 3 \mathrm{a}$ and $\mathrm{H} 3 \mathrm{~b}$ indicate that the user does not show concerns about the ease of use, operation, interaction, or navigation of the site. These items do not influence their intention to recommend or the continuity of use. In $\mathrm{H} 3 \mathrm{a}$, the causal relationship of the Usability and Intention to Continue Using path, with $\beta=-.002$ and test $\mathrm{t}=.051$ and in $\mathrm{H} 3 \mathrm{~b}$, and the causal relation of the Usability and Intention to Recommend path, with $\beta=.002$ and test $t=.046$.

Respondents in this survey have not shown concern about usability, possibly due to Internet contact on a day to day basis and the ability to navigate through websites. However, such users may not represent the general public accessing online tourism service sites. There are reports of companies that are worried about usability, since they found that they lost money in accesses where users could not successfully complete their goals, reducing user productivity, and increasing stress and dissatisfaction.

The main flaws of the product pages are: a) lack of prominence for the relevant information; b) lack of description of the product; c) lack of conquest (because they focus only on the final purchase action); d) use of images that do not help sell (images that do not show the details of the products); e) use of hard-to-read text (small font or low contrast text, or missing key information for purchase decision); f) navigation that does not promote the purchase, with the use of filters that cover the products; g) disregard of the product description, with incomplete or incorrect information, spelling or typing errors, or too much use of technical terms; and h) lack of prominence of the "purchase" button, among others. In this sense, in order to increase the chances of completed purchases, one should prioritize the relevant page to the consumer, facilitating the visualization of the paths of interest of the user, investing in quality images and the highlight of the purchase button, focusing on the product description in order for the site to be trusted. 
Table 4 - Analysis of the significance of the paths (comparative between High Experience and Low Experience)

\begin{tabular}{l|l|l|l|l|l|l|l|l|l|l}
\hline \multirow{2}{*}{ Hypotheses and Paths } & \multicolumn{2}{|c|}{$(\boldsymbol{\beta})$} & \multicolumn{2}{c|}{ Bootstrapping } & \multicolumn{2}{c|}{ SE } & \multicolumn{2}{c|}{ Statistic t } & \multicolumn{2}{c}{ p values } \\
\cline { 2 - 10 } & High & Low & High & Low & High & Low & High & Low & High & Low \\
\hline $\begin{array}{l}\text { H1a: Information -> Intention to } \\
\text { Continue Using }\end{array}$ & .113 & .347 & .146 & .353 & .073 & .095 & 1.542 & 3.662 & .124 & .000 \\
$\begin{array}{l}\text { H1b: Information -> Intention to } \\
\text { Recommend }\end{array}$ & .120 & .291 & .154 & .303 & .087 & .094 & 1.375 & 3.083 & .170 & .002 \\
$\begin{array}{l}\text { H2a: Service Interaction -> } \\
\text { Intention to Continue Using }\end{array}$ & .077 & .133 & .101 & .134 & .068 & .076 & 1.138 & 1.750 & .256 & .081 \\
$\begin{array}{l}\text { H2b: Service Interaction -> } \\
\text { Intention to Recommend }\end{array}$ & .148 & .213 & .152 & .211 & .078 & .087 & 1.893 & 2.446 & .059 & .015 \\
$\begin{array}{l}\text { H3a: Usability -> Intention to } \\
\text { Continue Using }\end{array}$ & .042 & -.058 & .074 & -.096 & .057 & .068 & .736 & .857 & .462 & .392 \\
$\begin{array}{l}\text { H3b: Usability -> Intention to } \\
\text { Recommend }\end{array}$ & -.021 & .004 & -.064 & .079 & .047 & .061 & .442 & .069 & .658 & .945 \\
\hline
\end{tabular}

Source: Research data.

When comparing the proposed groups, according to Table 4, it is observed that the group called High Experience presents some degree of significance in the H2b hypothesis, although this support is low ( $p<.1 \mathrm{t}=1.893)$, and no significance in the other hypotheses. It is observed that in this group there is a balance between respondents who buy online tourism service between young people up to 25 years old $(19 \%, \mathrm{n}=83)$ and older respondents $(18.08 \%, \mathrm{n}=79)$.

The user of the High Experience group neglects details in the navigation of the ecommerce sites of tourism services, as this is the same way in other sites of the type, with which they have contact in the day to day. Therefore, consumers adhere to the accuracy, clarity, and details of the information contained in the sites. They look for sites that offer services with good reputation, security, seriousness, and that comply with the delivery of the product/service that they aim for. But above all, these users want the company behind the site to understand their real need and meet their expectations.

The group called Low Experience presented a high degree of significance in hypothesis H1a $(\mathrm{p}<.001 \mathrm{t}=3.662)$, followed by H1b $(\mathrm{p}<.05 \mathrm{t}=3.083), \mathrm{H} 2 \mathrm{~b}(\mathrm{p}<.05 \mathrm{t}=$ 2.446) and $\mathrm{H} 2 \mathrm{a} \mathrm{p}<.10 \mathrm{t}=1.75$ ). This shows that, for the profile of the sample observed, mostly composed of young people up to 25 years of age $(52.17 \% \mathrm{n}=228)$, it is evident that, despite the predominant low frequency practice of using the online tourism service $(30.22 \% \mathrm{n}$ 
$=132)$, this profile has a high predisposition to purchase $(21.29 \% \mathrm{n}=93)$. In this case, "buyback" services, whether on airline websites, hotels, entertainment services, or direct from online service agencies, for example, have a high purchase rate $(16.48 \% \mathrm{n}=72)$.

The responsibility of the purchase is shared with relatives of the users, who execute the payment of the services. In this sense, not all online tourism services have the same payment system (for example, debit, number of times in credit, ticket, among others). Thus, families aid in costs, selecting, for convenience, the most appropriate payment option to the family budget. They often opt for the traditional system of sale in physical agencies.

In this study, considering the total sample, the $\mathrm{R}^{2}$ values of the constructs Intention to Continue Using (.105) and Intention to Recommend (.152) demonstrate that the model has precision and predictive relation.

In the $\mathrm{R}^{2}$ analysis a significant difference emerged between the groups Low Experience and High Experience. The Low Experience group shows $\mathrm{R}^{2}$ values higher than the values of the total sample of the constructs Intention to Continue Using (.220) and Intention to Recommend (.167), while the High Experience group presents values well below $\mathrm{R}^{2}$ for the constructs Intention to Continue Using (.050) and Intent to Recommend (.039). Thus, we can say that the Low Experience group represents the best model, since it presents the highest level of predictive accuracy and best explanatory scenario.

\section{Conclusions}

The model proposed in this work was developed to measure the antecedent factors of quality in websites that contribute to the experience in online tourism services, particularly with respect to the intention of continuity of use and recommendation.

In this sense, a theoretical model was developed that utilized several constructs: Usability, Information, and Service Interaction, from the original model by Barnes and Vidgen's (2002) and extended by Ahmad and Khan (2017). The constructs Intent to Continue Using and Intention to Recommend we readapted from the work of Reichheld and Markey (2012).

The study indicates that, for those who use the site more frequently, the considered variables (ease, information, safety) have no effect on loyalty and recommendation. Among the less frequent users, information is important, and safety has little effect on the recommendation. 
The model was considered partially valid, and the Usability construct did not present significant values, since it does not influence the intention to continue using or the intention to recommend. Users have expressed no concern about ease of use, operation, interaction, or navigation with respect to the sites. The results confirmed that these constructs have great explanatory power over the antecedent factors of quality in websites, which contribute to the experience in online tourism services in the intention of use and recommendation.

The sample, comprised primarily of young people, has long been consuming products and services over the web. In this context, the security of a website is already a minimum condition understood as incorporated. The same speculation could be made regarding perceived usability.

The causal relationship between information and intention to continue using presented the highest $\beta$ (.231), confirming the concept that information is necessary for the continuity of use of an online tourism service. Among the valid hypotheses, the one that presented a lower $\beta$ positive (.121) was verified in the causal relation between the constructs Service Interaction and Intention to Continue Using. An explanation for this lower $\beta$ can be the assumption that the security and delivery of the products/services are assumed prerequisites for the existence of the site, so users do not care much about these interaction items of the services.

With this study, it was concluded that some dimensions of information quality are more important than others for users, such as accuracy, reliability, relevance, adequate level of detail, and timing. The greater the perception of the quality of the information offered, the greater the perceived confidence. As well as the quality of information, perceived security also contributes to greater confidence (Escobar-Rodríguez \& Carvajal-Trujillo, 2014, Kim \& John, 2008 and 2011).

If an online tourism service website does not offer complete and accurate information, consumers may assess that it is not suitable for completing a purchase. Thus, the information provided by the site must be accurate, clear, timely, and sufficient in terms of depth of content, describing the characteristics of the travel product clearly and without technical terms. To increase consumer perceptions about timeliness and accuracy of information, the travel site may include a timestamp for the information (Kuan, Bock, \& Vathanophas, 2008).

\subsection{Management recommendations}

Both the theoretical framework and the research results highlight the role of ecommerce in the face of new trends, which have been modifying online tourism services. 
Online transactions represent a new stage for the tourism industry, which is working to develop best business practices (Kim, Chung, \& Lee, 2011). Users, more and more, look for greater convenience, optimization of the time, and better options of products and/or services. Companies must adapt to the new reality, avoiding losing space in the market in the long term, and serving the users who are influenced by the speed of information and are more connected to the manifestations in social networks, blogs, and online news.

The online tourism service companies should listen to the users' wishes to guide the strategies to increase their performance. It is essential that, in this process, they continue to guarantee the privacy of their customers' personal data, through technological security solutions, while maintaining user confidence. Although usability was not significant in this study, it could be used as a way to obtain competitive advantage. The investment in the site is a factor that plays a relevant role that contributes to perceived security and privacy (Ray, Ow, \& Kim, 2011). Usability is a critical determinant of a site's success, when success is measured by the user's satisfaction and likeliness to return to using the service (Agarwal \& Venkatesh, 2002).

Traditional companies, which have only physical stores, should streamline the process of adapting to this new business model, e-commerce, so that they can remain in their positions in the market or to maintain or achieve better positioning. The online presence of the company maintains greater visibility of its business, favoring the attraction of more consumers, expanding the virtual attendance, and narrowing the relations with the users. Increasingly, buyers move through various channels and points of contact, until they make a decision. Omnichannel is a concept that holds that all contact and sales platforms must be available to the consumer in an integrated way (Zhang et al., 2014).

Companies should invest, in addition to e-commerce, in m-commerce; that is, in platforms compatible with portable devices, such as smartphones, tablets, and laptops, as their use and demand is constantly increasing, with a trend towards continuous evolution (TurnerMcGrievy \& Tate, 2014). After all, generally, users of online tourism services, while traveling, take with them portable devices, as they serve as locators or even as tour guides and assist in banking transactions. Thus, the traveler could also, during the trip, search for accommodations, rent a car or book flight, for example (Hew et al., 2016). The smartphone is part of everyday life, including travel. Travel can be considered as a special step in the use of mobile technology in daily life, since the use of mobile technology is shaped by tourism experience rather than the opposite (Wang, Xiang, \& Fesenmaier, 2014). 
Online tourism services are not restricted to just the pre-trip, which was the target of this study. These services can also cover the stages during travel and post-trip. In addition, it is possible to broaden the reach of users and/or consumers through the technology of interactive websites, interactive ordering systems, interactive mobile platforms, and virtual travel, among other things (Neuhofer, Buhalis, \& Ladkin, 2014).

Finally, e-commerce and websites are essential tools for the sustainability of companies in terms of cost reduction, proximity, and direct marketing with the user or client. In a highly competitive and globalized world, access to information and convenience in services presupposes a better use of resources and a more attractive financial return to companies.

The initial limitation of this study may have been the application of the WEBQUAL 4.0 scale per se, as it did not present any significance in the usability construct. It may be necessary to update the scale for the use of new technologies and information systems. In spite of this, efforts were made to achieve the usability and design, quality of information by information, and quality of service interaction (safety and empathy).

In this sense, this study tried to make a reanalysis of the original model. We hope to have contributed to the literature by adapting two theoretical models into a single model that is more comprehensive than the originals. In addition, the model was tested at a time when digital platforms were better known by consumers when compared to the application conducted by Reichheld and Markey (2012).

Another limitation refers to the fact that travelers' electronic purchasing behavior was measured from a general perspective, regardless of the type of tourism, product, or service purchased. The types of travel product can modify the electronic purchasing behavior of travelers, because the level of perceived risk is dependent on the cost of the product and the level of tangibility (Hernandez, Jimenez, \& Martin, 2009).

Therefore, it is suggested for future research that psychological factors (for example, emotions and motivations) or social factors are explored (subjective norms are part of the models of use of electronic platforms for some time). This research agenda is important to understand, in addition to the antecedent factors of the intention to use / use recommendation, and the mental triggers that explain these antecedents. Furthermore, based on the results of the present study, additional comprehension of the role of safety and usability perceived by the consumer, principally through the identification of the respondent's (possible) moderation could shed light on the identified phenomenon. 


\section{References}

Agag, G. M., \& El-Masry, A. A. (2016). Why Do Consumers Trust Online Travel Websites? Drivers and Outcomes of Consumer Trust toward Online Travel Websites. Journal of Travel Research, 56(3), 347-369.

Agarwal, Ritu, and Viswanath Venkatesh. (2002). "Assessing a Firm's Web Presence: A Heuristic Evaluation Procedure for the Measurement of Usability." Information Systems Research, 13 (2), 168-86.

Ahmad, A., \& Khan, M. N., (2015a). Mapping online buyer behavior: A critical review of empirical studies. Pacific Business Review International, 8 (2), 37-48.

Ahmad, A., Rahman, O. \& Khan, M. N., (2016). Consumer's perception of website service quality: An empirical study. Journal of Internet Commerce, 15 (2), 125-41.

Ahmad, A., \& Khan M. N. (2017). Developing a Website Service Quality Scale: A Confirmatory Factor Analytic Approach. Journal of Internet Commerce, 16:1, 104-126.

Ahn, T., Ryu, S., \& Han, I. (2007). The impact of Web quality and playfulness on user acceptance of online retailing. Information and Management, 44, 263-275.

Amaro, S., \& Duarte, P. (2015). An integrative model of consumers' intentions to purchase travel online. Tourism Management, 46, 64-79.

Aye, J.K. \& Law, R. (2013b). "Predicting the Intention to Use Consumer Generated Media for Travel Planning." Tourism Management, 35:132-43.

Barnes, S. J. \& Vidgen, R. T. (2002). An integrative approach to the assessment of eommerce quality. Journal of Electronic Commerce Research, 3 (3),114-27.

Brasil, Ministério do Turismo (2018). Intenção de Viagem. Sondagem do Consumidor. Fundação Getulio Vargas. São Paulo.

Buhalis, D. (1998). Strategic use of information technologies in the tourism industry. Tourism Management, 19 (5), 409-421.

Buhalis, D. \& Law, R. (2008). Progress in information technology and tourism management: 20 years on and 10 years after the Internet. Tourism Management, 29(4), 609-623.

Cárdenas-García, P. J., Sánchez-Rivero, M. \& Pulido-Fernández, J. I. (2015). Does Tourism Growth Influence Economic Development? Journal of Travel Research, 54 (2), 206-21.

Chin W.W. (1998). The Partial Least Squares Approach for Structural Equation Modeling. "In GA Marcoulides (ed.), Modern Methods for Business Research, 295-336. Lawrence Erlbaum Associates, London.

Chu, R. (2001). What online Hong Kong travelers look for on airline/travel websites? International Journal of Hospitality Management, 20, 95-100.

Conger, S., Hefley, B., Galup,S. \& Dattero, R. (2012). Service Quality Measurement: Past and Future. Working Papers on Information System.

Cronin Jr., J. J. (2003). Looking back to see forward in services marketing: Some ideas to consider. Managing Service Quality: An International Journal, 13 (5), 332-37.

DeLone, H. W., \& McLean, R. E. (2003). The DeLone and McLean model of information systems success: A ten-year update. Journal of Management Information Systems, 19, 9-30.

Deng, L., \& Poole, M. S. (2012). Aesthetic design of e-commerce web pages-Webpage complexity, order and preference. Electronic Commerce Research and Applications, 11 (4), 420-40.

Do Valle, P. O., \& Assaker, G. (2015). Using Partial Least Squares Structural Equation Modeling in Tourism Research. Journal of Travel Research, 55(6), 695-708.

Dziuban, C. D., \& Shirlkey, E. C. (1974). When is a correlation matrix appropriate for factor analysis? Some decision rules. Psychological Bulletin, 81 (6), 358-361. 
Escobar-Rodíguez, T. \& Carvajal-Trujillo, E. (2014). Online purchasing tickets for low cost carriers: an application of the unified theory of acceptance and use of technology (UTAUT) model. Tourism Management, 43 (August), 70-88.

Ferguson, G., Megehee, C. M., \& Woodside, A. G. (2017). How Recipes of National Cultural Values, Wealth, Economic Inequality, and Religiosity Explain Consumer Tipping Behavior: An Abstract. In Creating Marketing Magic and Innovative Future Marketing Trends (pp. 1337-1337). Springer, Cham.

Filieri, R. (2015). "Why Do Travelers Trust TripAdvisor? Antecedents of Trust towards Consumer-Generated Media and Its Influence on Recommendation Adoption and Word of Mouth." Tourism Management, 51:174-85.

Fornell, C. \& Larcker, D. F. (1981). Evaluating structural equation models with unobservable variables and measurement error. Journal of marketing research, Vol. 18, No. 1 (Feb., 1981), pp. 39-50.

Gretzel, U., Y. H. Hwang, and D. R. Fesenmaier. (2012). "Informing Destination Recommender Systems Design and Evaluation through Quantitative Research." International Journal of Culture, Tourism and Hospitality Research, 6 (4): 2-2.

Hair, J. F., Black, W. C., Babin, B. J. \& Anderson, R. E. (2010). Multivariate Data Analysis: A Global Perspective, New Jersey, Pearson Prentice Hall.

Hair, J.F.; Hult, T.M.; Ringle, C.M. \& Sarstedt, M. (2014). A Primer on Partial Least Squares Structural Equation Modeling (PLS-SEM). SAGE. Los Angeles.

Hernandez, B., Jimenez, J., \& Martin, M. J. (2009). The impact of self-efficacy, ease of use and usefulness on e-purchasing: An analysis of experienced shoppers. Interacting with Computers, 21, 146-156.

Hew, J. J., Lee, V. H., Leong, L. Y., Hew, T.S. \& Ooi, K. B. (2016). The dawning of mobile tourism: what contributes to its system success? International J. Mobile Communications, 14 (2), 170-201.

Ho, C. I., \& Lee, L. Y. (2007). The development of an e-travel service quality scale. Tourism Management, 28, 1434-1449.

Hsu, Meng-Hsiang, Chuang Li-Wen, and Hsu Cheng-Se. 2014. "Understanding Online Shopping Intention: The Roles of Four Types of Trust and Their Antecedents." Internet Research, 24 (3): 332-52.

Jain, S. K. \& Gupta, G. (2004). Measuring service quality: SERVQUAL versus SERVPERF scales. Vikalpa, 23-35.

Kvålseth, T. O. (1985). Cautionary note about R ${ }^{2}$. The American Statistician, 39(4), 279-285.

Kim, H., \& John, D. R. (2008). Consumer response to brand extensions: construal level as a moderator of the importance of perceived fit. Journal of Consumer Psychology, 18 (2), 116-126.

Kim, M. J., Chung, N., \& Lee, C. K. (2011). The effect of perceived trust on electronic commerce: shopping online for tourism products and services in South Korea. Tourism Management, 32 (2), 256-265.

Kourtit, K., Nijkamp, P., van Leeuwen, E.S. \& Bruinsma, F. (2011). Evaluation of cyber-tools in cultural tourism, International Journal of Sustainable Development.

Kuan, H. H., Bock, G.W., \& Vathanophas, V. (2008). Comparing the effects of website quality on customer initial purchase and continued purchase at ecommerce websites. Behaviour \& Information Technology, 27(1), 3-16.

Lee, T. H. (2013). Influence analysis of community resident support for sustainable tourism development. Tourism Management, 34, 1-10.

Lee, Y., \& Kozar, A. K. (2006). Investigating the effect of website quality on ebusiness success: An analytic hierarchy process (AHP) approach. Decision Support Systems, 42, 1383-1401. 
Levin, J., Fox, J. A., \& Forde, D. R. (2013). Elementary Statistic in Social Research. Pearson, 12 edition (June 23).

Lin, S. P., Chan, Y. H., \& Tsai, M. C. (2009). A transformation function corresponding to IPA and gap analysis. Total Quality Management \& Business Excellence, 20, 829-846.

Madu, C. N., \& Madu, A. A. (2002). Dimensions of e-quality. International Journal of Quality and Reliability Management, 19 (3), 246-258.

Malhotra, N. K. (2014). Essencials of Marketing Research: A Hands-on Orientation. Prentice Hall, 1 Edition, January 20.

Mohd-Any, A. A., Winklhofer, H., \& Ennew, C. (2014). Measuring Users' Value Experience on a Travel Website (e-Value). Journal of Travel Research, 54(4), 496-510.

Munar, A. M., \& J. Jacobsen, J. K. S. (2013). "Trust and Involvement in Tourism Social Media and Web-Based Travel Information Sources." Scandinavian Journal of Hospitality and Tourism, 13 (1): 1-19.

Munar, A. M., \& Jacobsen, J. K. S. (2014). Motivations for sharing tourism experiences through social media. Tourism Management, 43, 46-54.

Neuhofer, B., Buhalis, D. \& Ladkin, A. (2014). A typology enhanced experiences, International Journal of Tourism Research, 16, 340-350.

Parasuraman, A., Zeithaml, V. A. \& Berry, L. L. (1985). A conceptual model of service quality and its implications for future research. The Journal of Marketing, 49 (4), 41-50.

Park, Y. J., Campbell, S. W., \& Kwak, N. (2012). Affect, cognition and reward: Predictors of privacy online. Computers in Human Behavior, 28(3), 1019-1027.

Pett, M., Lackey, N. \& Sullivan, J. (2003). Making sense of factor analysis. Thousand Oaks: Sage Publications, Inc.

Ray, S., Ow, T., \& Kim, S. S. (2011). Security assurance: how online service providers can influence security control perceptions and gain trust. Decision Sciences, 42 (2), 391-412.

Reichheld, F. F. \& Markey, R. (2012). The Ultimate Question 2.0. Harvard Business Review Press.

Schmidt, S., Cantallops, A. S., \& Santos, P. C. (2008). The characteristics of hotel websites and their implications for website effectiveness. International Journal of Hospitality Management, 27, 504-516.

Simon, H. A. (2001). Science seeks parsimony, not simplicity: Searching for pattern in phenomena. Simplicity, inference and modelling: Keeping it sophisticatedly simple, 32-72

Turner-McGrievy, G.M. \& Tate, D.F. (2014). Are we sure that mobile health is really mobile? An examination of mobile device uses during two remotely-delivered weight loss interventions. International Journal of Medical Informatics, 83 (5), 313-319.

UNCTAD (2017). Information Economy Report 2017. Digitalization, Trade and Development.

World Tourism Organization (2018), UNWTO Tourism Highlights, 2018. Edition, UNWTO, Madrid.

Wang, D., Xiang, Z., \& Fesenmaier, D. R. (2014). Smartphone Use in Everyday Life and Travel. Journal of Travel Research, 55(1), 52-63.

Werthner, H. \& Ricci, F. (2004) E-commerce and tourism. Communications of the ACM, 47 (12), 101-105.

Wolfinbarger, M. \& Gilly, M. C. (2003). eTailQ: Dimensionalizing, measuring and predicting etail quality. Journal of Retailing 79, 183-198.

WTTC (2018). Economic Impact 2017 Brazil. Travel and Tourism.

Yoo, B., \& Donthu, N. (2001). Developing a Scale to Measure the Perceived Quality of an Internet Shopping Site (SITEQUAL). Quarterly Journal of Electronic Commerce. 
Zeithaml, V. A., Parasuraman, A. \& Malhotra, A. (2000). Conceptual framework for understanding e-service quality: Implications for future research and managerial practice. Working Paper no. 00-115. Marketing Science Institute, Cambridge, MA.

Zeithaml, V.A., Parasuraman, A. \& Malhotra, A (2002). Service quality delivery through web sites: A critical review of extant knowledge. Journal of the Academy of Marketing Science, 30, (4), 362-375.

Zhang, H., Fu, X., Cai, L. A., \& Lu, L. (2014). Destination image and tourist loyalty: A metaanalysis. Tourism Management, 40, 213-223. 
Appendix A - Presentation of constructs, indicators, affirmatives and model references

\begin{tabular}{|c|c|c|c|}
\hline Constructs & Indicators & Affirmatives & References \\
\hline Usability & $\begin{array}{l}\text { US5 } \\
\text { US6 } \\
\text { US7 } \\
\text { US8 }\end{array}$ & $\begin{array}{l}\text { I find it easy to learn how to operate the online tourism service } \\
\text { website that I use the most. } \\
\text { It is very easy to interact with the online tourism service } \\
\text { website that I use the most. } \\
\text { I find it easy to navigate the online tourism service website } \\
\text { that I use the most. } \\
\text { I find it easy to use the online tourism service website that I } \\
\text { use the most. } \\
\text { The online tourism service website that I use the most has } \\
\text { attractive appearance. } \\
\text { The online tourism service website that I use the most has an } \\
\text { appropriate design. } \\
\text { The online tourism service website that I use the most seems } \\
\text { competent. } \\
\text { The online tourism service website that I use the most creates } \\
\text { a positive experience for me. }\end{array}$ & \multirow{3}{*}{$\begin{array}{c}\text { Ahmad e } \\
\text { Khan (2017) }\end{array}$} \\
\hline Information & $\begin{array}{l}\text { IN1 } \\
\text { IN2 }\end{array}$ & $\begin{array}{l}\text { The information of the online tourism service website that I } \\
\text { use the most is accurate. } \\
\text { The information of the online tourism service website that I } \\
\text { use most is reliable. } \\
\text { The online tourism service website that I use most provides } \\
\text { information in the moment I need it. } \\
\text { The information of the online tourism service website that I } \\
\text { use the most is relevant. } \\
\text { The information of the online tourism service website that I } \\
\text { use the most is easy to understand. } \\
\text { The information of the online tourism service website that I } \\
\text { use the most has appropriate level of detail. } \\
\text { The information of the online tourism service website that } \\
\text { most use has appropriate format. }\end{array}$ & \\
\hline $\begin{array}{l}\text { Service } \\
\text { Interaction }\end{array}$ & SI2 & $\begin{array}{l}\text { The online tourism service website that I use the most holds } \\
\text { great reputation. } \\
\text { It seems safe to complete the transactions on the online } \\
\text { tourism service website that I use most. } \\
\text { My personal information is kept securely on the online tourism } \\
\text { service website that I use the most. } \\
\text { I feel that the online tourism service website was customized } \\
\text { for my use. } \\
\text { The online tourism service website that I use the most makes } \\
\text { me feel in a social network. } \\
\text { The website of online tourism service that I use the most } \\
\text { facilitates a lot communication with the company. } \\
\text { I trust that the products/services of the online tourism service } \\
\text { website that I use the most will be delivered as promised. }\end{array}$ & \\
\hline $\begin{array}{l}\text { continu } \\
\text { recon }\end{array}$ & $\begin{array}{l}\text { E_using } \\
\text { mend }\end{array}$ & $\begin{array}{l}\text { Intention to continue using the website. } \\
\text { Intention to recommend the website to a friend. }\end{array}$ & $\begin{array}{c}\text { Reichheld e } \\
\text { Markey } \\
(2012) \\
\end{array}$ \\
\hline
\end{tabular}

Source: The authors. 


\section{T TMA VISÃO SOBRE A QUALIDADE DE WEBSITES E SEUS EFEITOS NA INTENÇÃO DE USO E NA RECOMENDAÇÃO DE SERVIÇOS TURÍSTICOS NOS DIFERENTES NÍVEIS DE EXPERIÊNCIA DO CONSUMIDOR}

Lenita Morimura

Bacharel em Administração pela Universidade Federal de São Paulo Analista de Planejamento de Numerário na TecBan - Tecnologia Bancária S.A. lenitamm@hotmail.com

Luis Hernan Contreras Pinochet Pós-doutor em Administração pela Universidade Nove de Julho Professor do Departamento Acadêmico de Administração da Universidade Federal de São Paulo luis.hernan@unifesp.br Livre docente em Marketing pela Universidade Federal de São Paulo e Pós-doutor em Marketing pela Universidade Federal de Minas Gerais
Pós-graduação em Administração da Universidade Nove de Julho e Professor do Departamento Acadêmico de Administração da Universidade Professor do Programa de Pós-graduação em Administração da Universidade Nove de Julho e Professor do Departamento Acadêmico de Administração da Universidade
Federal de São Paulo
elldijo@uol.com.br Professor do Programa de Pós-graduação em Administração da Universidade Nove de Julho e Professor do Departamento Acadêmico de Administração da Universidade
Federal de São Paulo
elldijo@uol.com.br

Eliane Herrero Doutoranda em Administração pela Universidade Nove de Julho e Mestre em Administração pelas Faculdades Metropolitanas Unidas Ârea de trabalho: liaherrero@gmail.com

Miriam Christi Midori Oishi Nemoto Doutora em Administração pela Faculdade de Administração, Economia e Contabilidade da Universidade de São Paulo. Professora do Departamento Acadêmico de Administração da Universidade Federal de São Paulo miriam.oishi@unifesp.br

Objetivo: A expansão do comércio eletrônico contribui com uma parcela considerável das receitas de grandes empresas do setor de turismo. As empresas modernas devem empregar ferramentas baseadas na Web, oferecendo a melhor experiência aos usuários, a fim de satisfazerem seus consumidores e impulsionarem seus negócios. Portanto, com este estudo, buscamos analisar os fatores que contribuem para a classificação da qualidade dos sites de serviços de turismo online, por meio da intenção de uso e recomendação para diferentes níveis de experiência do consumidor.

Método: A pesquisa ocorreu em uma amostra de 437 questionários válidos, utilizando um instrumento de coleta estruturado em escala Likert, com 22 afirmações baseadas na escala WEBQUAL 4.0, e duas afirmações com base na escala proposta para o Net Promoter Score (NPS). Os modelos utilizados foram de Reichheld e Markey (2012) e Ahmad e Khan (2017).

Resultados: Como resultado, verificamos que a predominância de usuários emprega serviços de turismo online com pouca frequência, o que nos permitiu estabelecer uma diferenciação entre dois grupos: Baixa Experiência e Alta Experiência.

Contribuições teóricas: O estudo indica que, para quem utiliza os sites com maior frequência, as variáveis consideradas (facilidade, informação, segurança) não têm efeito na lealdade e recomendação. Entre os usuários menos frequentes, as informações são importantes e a segurança tem pouco efeito sobre a recomendação. Portanto, descobrimos que os entrevistados desta pesquisa não consideram a facilidade de uso como premissa para a continuidade do uso ou recomendação de serviços de turismo online, independentemente de seu nível anterior de experiência.

Contribuições gerenciais: a identificação dos antecedentes da intenção de usar serviços online no processo de consumo turístico possibilita que os gerentes aprimorem ações em plataformas digitais. Essa é uma maneira de incentivar os usuários a executar transações comerciais.

Contribuições sociais: A baixa relevância para a segurança do site é uma questão que surge dos resultados obtidos neste estudo. Embora esse fenômeno possa ser parcialmente explicado pela (baixa) idade dos entrevistados, existe uma oportunidade para as agências reguladoras e de proteção ao consumidor tomarem medidas para garantir que os requisitos mínimos de segurança estejam presentes nos operadores turísticos online.

Palavras-chave: Turismo. Comércio eletrônico. Qualidade. Intenção de continuar usando. Intenção de recomendar.

\section{Como citar}

American Psychological Association (APA)

Morimura, L., Pinochet, L. H. C., Lopes, E. L., Herrero, E., \& Nemoto, M. C. M. O. (2020). Uma visão sobre a qualidade de websites e seus efeitos na intenção de uso e na recomendação de serviços turísticos nos diferentes níveis de experiência do consumidor. Revista Brasileira de Marketing, 19(2), 248-274. https://doi.org/10.5585/remark.v19i2.16118. 


\section{Introdução}

O turismo moderno representa uma importante fonte de renda interna para muitos países (OMT, 2018), contribuindo para a criação de empregos, melhorias na infraestrutura e qualidade de vida (Cárdenas-García, Sánchez-Rivero \& Pulido-Fernández, 2015). O turismo também está ligado ao desenvolvimento dos destinos, por meio da melhoria da qualidade e infraestrutura dos locais. Dado seu caráter, o turismo é sinônimo de crescimento para outras indústrias inter-relacionadas, como a indústria de serviços, pois atende a várias classes de pessoas.

Em 2018, o setor de turismo mostrou crescimento contínuo, alcançando o maior patamar de 7\% no ano de 2018 (OMWTO, 2018), superando os sete anos anteriores que mostraram crescimento, em média de $4 \%$. Turismo é o terceiro setor de mais rápido crescimento no mundo. Além disso, a conta do turismo representa 10,4\% do Produto Interno Bruto (PIB) do mundo, com 1,3 bilhão de turistas internacionais, e 1,8 bilhão projetados até 2030. O turismo é a terceira grande categoria de exportação, atingindo US\$ 1,3 trilhão. No Brasil, em 2017, a contribuição direta do setor de turismo representou US \$ 59,6 bilhões, ou 2,9\% do PIB total, com previsão de aumento de 2,5\% em 2018. A contribuição indireta representou U \$163,0 bilhões (7,9\% de o PIB brasileiro), de acordo com o relatório anual do Conselho Mundial de Viagens e Turismo (WTTC, 2018).

No setor de turismo, assim como em outros, a expansão do comércio eletrônico representa uma parcela considerável das receitas dos grandes varejistas. O Brasil, com 120 milhões de usuários online em 2015, é o quarto maior país em relação ao número absoluto de turistas, atrás apenas dos Estados Unidos, Índia e China (UNCTAD, 2017).

De acordo com o Ministério do Turismo (BRASIL, 2018), a crescente iniciativa em relação à busca e comparações entre preços de passagens, acomodações e meios de transporte fornecidos por sites de internet fazem do serviço de turismo online um segmento lucrativo para o comércio eletrônico. Os dados da Pesquisa do Consumidor - Intenção de Viajar (BRASIL, 2018) mostram que a intenção do brasileiro de viajar atingiu 24,3\% até março de 2019.

Essa revolução virtual causou mudanças nas agências de turismo, pois mesmo aquelas que possuem lojas físicas também criam opções de compras, por meio de ferramentas virtuais (Park, Campbell, \& Kwak, 2012). Embora a tecnologia ainda não substitua certos aspectos da interação humana, como cortesia, simpatia, utilidade, assistência, comprometimento e flexibilidade, as empresas devem empregar ferramentas baseadas na Web para oferecerem a 
melhor experiência ao usuário e satisfazerem seus consumidores (Ahmad, Rahman \& Khan, 2016). A qualidade do site desempenha papel importante na forma e na comunicação da imagem, como pano de fundo das diferenças culturais (Deng \& Poole, 2012). A qualidade do serviço eletrônico também apresenta potencial em termos estratégicos, contribuindo, consequentemente, para a rentabilidade da empresa (Zeithaml, 2002; Cronin, 2003).

No geral, os pesquisadores estão interessados em investigar o comportamento do consumidor online (Ahmad \& Khan, 2015; Ahmad, Rahman \& Khan, 2016), incluindo aqueles que usam serviços de turismo. Pesquisadores como Ferguson, Megehee e Woodside (2017) tentam explicar o comportamento desses usuários sob três perspectivas: a) perfil do consumidor; b) uso da Internet; e c) atitudes em relação às compras online.

Além da qualidade dos sites, este artigo busca estabelecer a relação entre esses três construtos e o comportamento do consumidor, no que diz respeito à continuidade do uso do serviço e à intenção de recomendar o serviço a terceiros (Reichheld \& Markey, 2012).

A contribuição potencial do artigo é a comparação de efeitos entre usuários frequentes e pouco frequentes. Assim, o objetivo foi analisar os fatores antecedentes de qualidade em sites que contribuem para serviços de turismo online, com relação à intenção do consumidor de continuar a usar e recomendar o serviço, dados diferentes níveis de experiência desse consumidor. Entendemos que, dado o crescimento do mercado de turismo, aliado ao surgimento de várias plataformas digitais no segmento, é relevante um estudo que identifique os fatores antecedentes da declaração de intenção de utilizar ferramentas online nesse cenário.

Este estudo está estruturado em quatro outras seções, além desta breve introdução, a saber: referencial teórico, que sustenta a construção do modelo teórico e as hipóteses testadas na fase empírica do estudo, o método, que norteou a fase empírica, os resultados e, finalmente, as conclusões e considerações finais.

\section{Fundamentos teóricos}

Nesta seção, os tópicos abordados são comércio eletrônico, qualidade do site, comportamento do consumidor e turismo.

\subsection{Comércio eletrônico}

O comércio eletrônico é um mercado da internet no qual são realizadas transações de compra e venda, de maneira semelhante aos mercados tradicionais. No entanto, no comércio 
eletrônico, o usuário pode escolher, reservar, comprar e ter pedidos respondidos, enquanto está em casa (UNWTO, 2018), uma vez que a transação é feita online. O comércio eletrônico também pode ser definido como a troca de produtos, serviços, bens e ideias ou comunicações por meios eletrônicos, com o objetivo de facilitar ou conduzir negócios, e pode envolver a solicitação, pagamento e entrega efetiva de bens ou serviços.

A adoção e uso do comércio eletrônico no setor de turismo criaram oportunidades para a introdução de práticas de negócios, pela capacidade de reduzir custos e melhorar a produtividade, que favorecem o crescimento. Portanto, empresas de turismo que usam inovações em TI fortalecem sua vantagem competitiva.

A importância da internet e do comércio eletrônico no turismo é destacada por Werthner e Ricci (2004), que apontam que o comércio eletrônico pode gerar crescimento de receita no setor. O sucesso vem da complementaridade dos dois segmentos, porque o setor de turismo é uma área de informações intensivas, e o comércio eletrônico e a internet podem influenciar a experiência e aumentar o turismo. Os consumidores também se tornaram cada vez mais poderosos, sofisticados e experientes e são capazes de determinar os elementos que compõem seus produtos turísticos. Assim, a intensa concorrência entre sites de viagens exige que as empresas entendam como seus usuários comparam sites (Mohd, Winklhofer, \& Ennew, 2014). O comércio eletrônico permite que as informações fluam em todo o mundo, praticamente sem barreiras de entrada, permitindo um espaço no qual os turistas podem acessar as informações de que precisam, personalizar suas viagens e terem a opção de fazer compras (Kourtit et al., 2011; Munar \& Jacobsen, 2014).

\subsection{Qualidade dos sites e modelos de avaliação}

A qualidade dos sites é um pré-requisito para o marketing digital eficaz. No entanto, seu processo é complexo e cheio de critérios de medição multidimensionais. A mensuração da qualidade pode ser representada por um modelo composto por três fatores: qualidade da informação, qualidade do sistema e qualidade do serviço (DeLone \& McLean, 2003). Lee e Kozar (2006) afirmam que a qualidade da informação é o primeiro indicador visível de um site e refere-se à comunicação produzida e disponibilizada, avaliada pelo usuário. Portanto, as informações devem ser relevantes, completas e fáceis de entender.

Para verificar a qualidade do sistema, é necessário medir a personalização, a navegabilidade e a segurança do software e do próprio site. A personalização é integrada como uma interface individualizada, com informações direcionadas e serviços adequados para 
cada usuário (Lee \& Kozar, 2006). A navegabilidade é apresentada com menus estruturados, com links para a homepage, páginas da web padrão e ferramentas de busca (Schmidt, Cantallops, \& Santos, 2008). Finalmente, a segurança corresponde a altos níveis de privacidade para transações online (Zeithaml, Parasuraman, \& Malhotra, 2002). A qualidade do serviço influencia a lealdade do usuário e é fundamental para o sucesso da empresa (Lin, Chan, \& Tsai, 2009). Assim, é necessário detectar falhas na prestação de serviços. Além disso, usuários online optam por sites fácies de usar, links úteis, conexões rápidas, independente de procurarem por informações ou desejarem fazer reservas (Ho \& Lee, 2007).

A avaliação da qualidade na área de marketing deriva de trabalhos desenvolvidos desde 1985, por Parasuraman, Zeithaml e Berry, autores que desenvolveram o modelo SERVQUAL, que avalia, por dimensões, o diferencial entre as expectativas do cliente e o serviço prestado. Na década de 1990, foi desenvolvido o SERVPERF (Jain \& Gupta, 2004; Conger et al., 2012), uma simplificação do modelo SERVQUAL, com redução do número de perguntas e de sua subjetividade. A primeira aplicação desse modelo nos sites foi denominada e-SERVQUAL e foi desenvolvida por Zeithaml, Parasuraman e Malhotra (2000).

Além disso, em 2000, Barnes e Vidgen apresentaram o modelo WEBQUAL. O indicador principal consistia na utilidade do site, levando em consideração a percepção e a interação do usuário. Posteriormente, os autores apresentaram o modelo WEBQUAL, analisando a qualidade da transação online como reflexo da qualidade do serviço prestado (Barnes \& Vidgen, 2002). Embora sejam baseados nas impressões subjetivas dos usuários, os dados coletados no modelo permitem uma análise quantitativa e elaboração de métricas de comércio eletrônico.

Posteriormente, foi criado o WEBQUAL 2.0, com uma coluna inicial preenchida, sem, no entanto, associar simultaneamente os dois construtos (qualidade da transação e serviço prestado). No WEBQUAL 3.0, foram definidos três tópicos: qualidade do site, qualidade da informação e qualidade da interação. Esse modelo foi substituído pelo WEBQUAL 4.0, depois que as falhas foram tratadas e a usabilidade, entendida como facilidade de uso, foi aumentada. A qualidade do software também foi aprimorada para que o foco não se restringisse ao design e ao software, mas para verificar as percepções do usuário.

Assim, com a evolução do comércio eletrônico, a medição correta das interações dos usuários com as empresas nos sites é um elemento crítico na avaliação geral da qualidade do serviço pelo cliente. No caso dos serviços de turismo, a concorrência global e a necessidade 
de reduzir custos tornam o comércio eletrônico um canal muito relevante, sendo que existem empresas que operam apenas dessa maneira.

\subsection{Comportamento do Consumidor}

O comportamento do consumidor é descrito como a atividade mental, emocional e psicológica que as pessoas usam durante a seleção, compra, uso e pós-compra de produtos e / ou serviços que atendem às suas necessidades e desejos. A decisão de compra do consumidor é altamente influenciada por quatro características: fatores culturais, sociais, pessoais e psicológicos (Ferguson, Megehee, \& Woodside, 2017). Embora esses fatores sejam incontroláveis, eles devem ser considerados para entender o comportamento.

O consumo na indústria do turismo é fortemente influenciado pelo otimismo e confiança das pessoas que vivem em países com crescimento econômico, emprego e paz (Lee, 2013). Nesse contexto, o consumidor de turismo tornou-se intensamente participativo, buscando informações sobre benefícios, preços, relatos de experiências, avaliações de produtos e serviços. Além disso, ao acessar a internet, os consumidores turísticos podem verificar as ofertas que desejam e que estão de acordo com o que estão dispostos a pagar, pesquisando em sites de fornecedores, sites de busca, sites de comparação de preços ou redes sociais.

\section{Modelo e Hipóteses}

A presente pesquisa é dedicada à análise de fatores de sites que contribuem para a qualidade e o uso de serviços de turismo online que influenciam a intenção de continuar usando e a intenção de recomendar. As escalas usadas para esse fim são apresentadas no apêndice A.

Neste artigo, pretendemos determinar os fatores para sites de serviços de turismo online que aumentam a qualidade. Assim, elaboramos hipóteses que testam a influência de cada dimensão do modelo WEBQUAL 4.0, criado por Barnes e Vidgen (2002), e o modelo de "The definitive question - A questão definitiva", determinada por Reichheld e Markey (2012), originada no estudo anterior de Reichheld (2003): Net Promoter Score (NPS). Em suma, as hipóteses testam a influência da qualidade percebida no comportamento do consumidor com relação à intenção de continuar usando ou recomendando sites de serviços de turismo online. 
“A questão definitiva" proposta por Reichheld e Markey (2012) é a que apresentou o maior grau de correlação com o comportamento esperado de um consumidor fiel: "Qual é a probabilidade de você nos recomendar (a empresa) a um amigo?" No entanto, note-se que existem condições a serem satisfeitas para os consumidores antes que estes recomendem ou indiquem a empresa em seus círculos sociais de maneira positiva. Primeiro, o cliente precisa acreditar que a organização oferece valores superiores em termos de funcionalidade, facilidade de uso, qualidade, características físicas, preço ou outros fatores que podem, em certa medida, ser expressos em termos econômicos. Além disso, o relacionamento que os consumidores mantêm com a empresa deve fazê-los se sentir bem, ou seja, os usuários devem acreditar que a empresa conhece, entende e ouve seus valores pessoais e compartilha os mesmos princípios. Portanto, os clientes devem continuar usando o produto e/ou serviço para que possam recomendar. O construto Informações do modelo WEBQUAL condiciona os diferentes perfis de usuários, que percebem a qualidade das informações produzidas e disponibilizadas (Lee \& Kozar, 2006), sendo o primeiro indicador visível de um site (DeLone \& McLean, 2003). As primeiras hipóteses da pesquisa são assim observadas:

H1a: As informações influenciam positivamente a intenção de recomendar serviços de turismo online.

H1b: As informações influenciam positivamente a intenção de continuar usando os serviços de turismo online.

A interação do serviço do modelo WEBQUAL abrange os diferentes perfis de usuário, para os quais a interação do serviço é considerada pela acessibilidade, velocidade e capacidade de busca de informações (Madu \& Madu, 2002). A segurança é importante para o usuário, pois fornece altos níveis de privacidade para transações online (Zeithaml, Parasuraman e Malhotra, 2002). A segurança do site protege informações nas transações contra ameaças de terceiros (Chu, 2001). Assim, elaboramos as hipóteses:

H2a: A interação do serviço influencia positivamente a intenção de recomendar serviços de turismo online.

H2b: A interação do serviço influencia positivamente a intenção de continuar usando os serviços de turismo online.

A construção Usabilidade do modelo WEBQUAL condiciona os diferentes perfis de usuário. Nesta dimensão, a percepção da qualidade dos sites do serviço de turismo online está diretamente relacionada à experiência de usar e perceber a autoeficácia (Yoo e Donthu, 2001). 
Um bom desempenho do site oferece maior comodidade, privacidade e resposta rápida (Ahn, Ryu \& Han, 2007). Assim, são formuladas essas hipóteses da pesquisa:

H3a: A usabilidade influencia positivamente a intenção de recomendar serviços de turismo online.

H3b: A usabilidade influencia positivamente a intenção de continuar usando os serviços de turismo online.

\section{Método}

Este estudo caracteriza-se como uma abordagem quantitativa transversal (Malhotra, 2014), com coleta de dados realizada de 11 a 31 de setembro de 2017, por meio de uma pesquisa, replicando e adaptando o estudo de modelos de Reichheld e Markey (2012) e Ahmad e Khan (2017) para a realidade brasileira. Para essa adaptação, utilizamos o processo de tradução reversa e, antes da aplicação, submetemos o questionário a uma verificação para compreensão do pré-teste, realizado com 25 sujeitos.

O questionário foi baseado em aspectos teóricos divididos e agrupados em construtos, que tratam do mesmo aspecto. Coletamos dados por meio de listas de e-mail, com a pesquisa online QuestionPro e o ambiente online, usando as redes sociais: Facebook e WhatsApp, pois estas desempenham um papel importante na criação de confiança (ou desconfiança) para uma determinada marca ou empresa. As conversas de cliente para cliente que ocorrem nessas plataformas estão cada vez mais informando as atitudes, crenças e níveis de confiança em relação às empresas (Munar \& Jacobsen, 2013).

Os indivíduos foram selecionados por conveniência e caracterizados como um grupo presente nas redes sociais e concentrado na cidade de São Paulo. Os dados foram coletados por meio de um questionário estruturado, com escala Likert de cinco pontos, variando de (1) "discordo totalmente" a (5) "concordo totalmente". Havia também um segundo bloco de perguntas para coletar informações demográficas e avaliar outras questões relacionadas ao uso dos serviços de turismo online, com o objetivo de estabelecer o perfil dos entrevistados.

Os dados foram purificados para análise e os outliers foram eliminados. O processo de purificação do banco de dados foi finalizado com a retirada de 121 (29 cujos respondentes não responderam a mais de $10 \%$ dos questionários e 92 cujos entrevistados usaram apenas um ou dois pontos da escala Likert em todas as respostas), deixando um total de 437 observações.

A Análise Fatorial Exploratória (AFE) e a Modelagem de Equações Estruturais (MEE) permitiram verificar ajustes entre os dados observados e o modelo teórico especificado a 
priori. Para identificar o perfil da amostra, foi utilizada estatística descritiva. A AFE foi realizada com o apoio do software IBM SPSS 22 e a Modelagem de Equações Estruturais, realizada por meio da análise de mínimos quadrados parciais (PLS) (Chin, 1988), realizada com o uso do software SmartPLS 3.0.

Na pesquisa em turismo, o uso do PLS-SEM é comum, uma vez que a lógica utilizada é uma revisão mais abrangente, permitindo uma avaliação mais eficaz do contexto da pesquisa e seu uso está aumentando na pesquisa de negócios e turismo. O PLS-SEM é uma técnica alternativa ao CB-SEM tradicional, pois oferece maior flexibilidade às suposições de dados, tamanho da amostra e análise de modelos complexos, devido às suas construções "reflexivas", que permitem testes de relação preditiva entre os construtos. Essas características tornam o PLS-SEM particularmente útil para pesquisadores de turismo, tornando-o nossa melhor ferramenta de pesquisa para este trabalho (Do Valle \& Assaker, 2015).

\section{Análise de dados}

O objetivo desta seção é apresentar os resultados da análise dos dados empíricos, que envolveram análises fatoriais descritivas, exploratórias e multivariadas.

\subsection{Características dos entrevistados e uso de serviços de turismo online}

Para a análise demográfica dos entrevistados desta pesquisa, descobrimos que, entre homens $(41,19 \% ; \mathrm{n}=180)$ e mulheres $(52,40 \% ; \mathrm{n}=229)$, mais da metade $(52,17 \% ; \mathrm{n}=228)$ tem 25 anos ou são mais jovens. A maioria $(94,73 \%, \mathrm{n}=204)$ está matriculada em cursos de graduação, 38,7\% $(\mathrm{n}=146)$ e possuem renda familiar entre $\mathrm{R} \$ 4.852,00$ e $\mathrm{R} \$ 9.254,00(1 \mathrm{R}$ $\$=\mathrm{US} \$ 0,26)$.

Os usuários indicaram baixa frequência de uso dos serviços de turismo online, e 53\% $(n=213)$ endossaram a opção "Uma vez por ano ou menos" e 31,3\% $(n=126)$ indicaram "Duas vezes por ano" $(31,3 \%, \mathrm{n}=126)$. Quase $85 \%$ dos entrevistados contrataram algum serviço de turismo, e a frequência de uso não é diretamente proporcional à contratação de serviços.

Além disso, os mesmos usuários, que são de baixa frequência, são os que contratam serviços para passar férias $(46,27 \%, \mathrm{n}=186$, para os marcados como "Uma vez por ano ou 
menos" e $26,87 \%, \mathrm{n}=108$, para aqueles que indicado "Duas vezes por ano") em seus destinos de viagem.

Foi possível verificar a predominância de compras "soltas". Uma compra solta é uma compra feita diretamente das companhias aéreas, hotéis ou sites de serviços de entretenimento. Essas compras representam mais da metade das respostas $(53,50 \%, \mathrm{n}=204)$, em oposição às compras diretas de agências de serviços online, únicas ou em pacotes $(44,70 \%, \mathrm{n}=178)$. Também, entre os entrevistados, a baixa frequência de uso dos serviços de turismo online é predominante para todos os tipos de transações: reservar um voo, reservar acomodações, comprar um pacote turístico, alugar um carro, entre outros.

Em relação à avaliação dos serviços de turismo online, entre os sites listados, $80 \%$ nunca foram utilizados por mais de $50 \%$ dos entrevistados. Somente os sites Gol, Latam e Decolar.com foram identificados por mais da metade dos entrevistados. Além disso, apenas o Decolar.com foi classificado como muito bom $(20,40 \%)$ e não foi possível estabelecer um parâmetro de comparação entre os sites.

\subsection{Primeira Fase Multivariada: Análise Fatorial Exploratória (AFE)}

Após analisar as respostas dos questionários, verificamos que a pergunta que melhor explica os resultados da amostra foi: "Com que frequência você utiliza os seguintes serviços de turismo online: reservar um voo, reservar acomodações, comprar um pacote turístico e alugar carro." As âncoras usadas forma de 1 - não frequentes e, 7 - com muita frequência. A partir dessa questão, foi criada uma variável de medida para indicar a frequência de uso dos serviços de turismo em sites relacionados a voos, acomodações, pacotes e aluguel de carros.

Nesse sentido, foi realizada uma AFE com essas quatro variáveis, nas quais o interesse estava centrado, principalmente, nos fatores comuns, que são interpretados em relação às variáveis observadas (Hair et al., 2014). A primeira análise ocorreu por meio da matriz de pontos em comum. Na primeira iteração, a variável freq_pack indicou 0,427 e, portanto, foi descartada. Quando uma nova AFE foi realizada, todos os pontos em comum apresentaram valores superiores a $0,5\left(h^{2}\right.$ freq_flight $=0,769 ; h^{2}$ freq_accom $=0,721 ; h^{2}$ freq_car $\left.=0,616\right)$.

Para esta análise, utilizamos o critério de Kaiser-Meyer-Olkin (KMO) e o Teste de Esfericidade de Bartlett (Dziuban \& Shirkey, 1974). Nesse caso, verificamos que o KMO = 0,680 apresenta um resultado adequado. No caso do teste de esfericidade de Bartlett, o resultado foi significativo, com $\mathrm{p}<0,001$. Após esses procedimentos, observamos a carga fatorial cruzada e algumas variáveis foram excluídas. Foram observados o escore de 
unidimensionalidade (escore $>0,50$ no fator) e o escore baixo de carga cruzada (escore $<0,40$ nos outros fatores) (Levin, Fox, \& Forde, 2013). Todas as variáveis apresentaram ajustes devido à semelhança $\left(\mathrm{h}^{2}<0,5\right)$ e coeficientes fracos $(<0,4)$. No final, as cargas foram ajustadas para um fator com três itens, o que explicava $79,19 \%$ da variância total da amostra $(\alpha=$ 0,787). A AFE resultou na extração de apenas um componente, chamado Experimento (freq_flight, freq_accom e freq_car). A variável mensuração foi construída com base na média da Experiência $(\bar{x}=3,16)$, sendo subdividida em dois grupos: Baixa Experiência e Alta Experiência. O grupo Baixa Experiência foi constituído por 228 indivíduos, representando $52,2 \%(\bar{x}=1,81)$ da amostra, e o grupo Alta Experiência foi formado por 209 indivíduos, representando $47,8 \%(\bar{x}=4,82 ; \mathrm{t}(411)=30,55, \mathrm{p}<0,01)$.

A diferenciação dos dois grupos se deve à frequência de uso de serviços de turismo online em sites, nos quais o grupo denominado Baixa Experiência corresponde aos respondentes que os utilizam com baixa frequência e, portanto, têm menos experiência. Por outro lado, o outro grupo, denominado Alta Experiência, corresponde aos usuários que utilizam os serviços com alta frequência.

\subsection{Segunda Fase Multivariada: Estimativa e Modelagem de Equações Estruturais}

A normalidade dos dados foi verificada por meio do teste não paramétrico Komolgorov-Smirnov. Todos os valores individuais do teste K-S, referentes aos indicadores, foram significativos, com $\mathrm{p}<0,01$. Em relação às variáveis dependentes Intenção de recomendar e Intenção de continuar usando, foi identificada a ausência de multicolinearidade dos dados, uma vez que todos os valores do fator de inflação de variação (VIFs) estavam abaixo de 5 .

Após estabelecerem-se os dois grupos a serem estudados (Alta Experiência e Baixa Experiência), com a variável de medida indicada (Experimento), foi criada a construção de diagramas de caminhos das relações estabelecidas, permitindo a visualização de relações derivadas de construtos.

Inicialmente, o modelo de medição foi avaliado e foram necessários ajustes, com a retirada de itens que apresentavam baixas cargas fatoriais. Esse raciocínio é ilustrado pelo argumento de Pett, Lackey e Sullivan (2003) sobre o desenvolvimento de uma das escalas, que envolve interesses mais direcionados às construções do que aos itens usados para medilas. 
A análise do modelo de medição deve preceder a análise dos relacionamentos entre as variáveis latentes. Assim, o próximo passo foi examinar as variações médias extraídas (AVEs) e validade convergente, validade discriminante, correlações quadráticas entre os constructos e confiabilidade composta. Na primeira iteração, os itens SI4 =0,452 e SI5 = 0,110 foram removidos. Então, no ajuste da AVE, os itens US5 = 0,519; IN5 = 0,612; SI6 = 0,$552 ;$ US6 $=0,533 ;$ e, finalmente, o item IN7 $=0,661$ também, para o ajuste de validade convergente.

Entretanto, ao realizar a análise de Validade Discriminante, observamos que os construtos Usabilidade e Interação de Serviço apresentaram correlações excessivas, sendo necessário excluir os itens US7 $=0,637$; SI1 $=0,725$ e US8 $=0,644$, para ajuste do modelo. Os itens das escalas passaram por um processo de tradução reversa e foram validados na fase exploratória da análise fatorial. Assim, não há problema teórico na construção das escalas originais; sua exclusão foi devida ao rigor na condução da análise estatística que, como afirma Simon (2001), deveria resultar em alguma eliminação.

Como todas as variáveis de um questionário usam a mesma escala de medida, o coeficiente é calculado a partir da variação dos itens individuais. Os Alphas de Cronbach variaram de 0,711 a 1,00, com valores entre 0,60 e 0,75 sendo considerados moderados e de 0,75 a 0,90, altos (Malhotra, 2014). As confiabilidades compostas variaram de 0,837 a 1,00 e foram consideradas adequadas. No modelo aqui proposto, são apresentados os resultados das cargas fatoriais obtidas por cada um dos construtos, observando-se os valores das cargas fatoriais de cada uma das variáveis, que apresentaram valores acima de 0,5 (Figura 1).

Neste estudo, os AVEs variaram entre 0,516 e 1. Para esta análise, foram utilizados os critérios de Fornell e Larcker (1981), que determinam que os valores de AVE devem ser maiores que 0,5. Nesse sentido, todas as variáveis latentes apresentaram variância média extraída maior que 50\%, o que atende aos critérios de Chin (1988) e Hair et al. (2010) para indicar a existência de validade convergente. Além disso, o $\mathrm{R}^{2}$ demonstrou que o modelo possui precisão e relevância preditiva em relação ao construto Intenção de continuar usando (.105) e Intenção de recomendar (.152). Embora os indicadores não tenham apresentado escores gerais altos, concordamos com Kvålseth (1985) sobre o $\mathrm{R}^{2}$, que deve ser considerado como um indicador de qualidade de ajuste e não como um indicador absoluto e definitivo do modelo regressivo. Os indicadores finais são apresentados na Tabela 1. 
Tabela 1 - Validade discriminante

\begin{tabular}{lccccc}
\hline & $\mathbf{1}$ & $\mathbf{2}$ & $\mathbf{3}$ & $\mathbf{4}$ & $\mathbf{5}$ \\
\hline 1- Informação & $\mathbf{0 , 7 1 8}$ & & & & \\
2- Intenção de Continuar Utilizando & 0,312 & $\mathbf{1 , 0 0 0}$ & & & \\
3- Intenção de Recomendar & 0,361 & 0,813 & $\mathbf{1 , 0 0 0}$ & & \\
4- Interação do Serviço & 0,685 & 0,278 & 0,355 & $\mathbf{0 , 7 9 4}$ & \\
5- Usabilidade & 0,713 & 0,234 & 0,279 & 0,590 & $\mathbf{0 , 8 4 9}$ \\
\hline
\end{tabular}

Nota: a diagonal em destaque apresenta as raízes quadradas da AVE.

Fonte: Dados da pesquisa.

Os indicares de ajustes gerais demonstram a adequação do modelo final, como visto na Tabela 2.

Tabela 2 - Indicadores da validade convergente

\begin{tabular}{lcccc}
\hline & $\begin{array}{c}\text { Alfa de } \\
\text { Cronbach } \\
>0,7\end{array}$ & $\begin{array}{c}\text { Confiabilidade } \\
\text { composta } \\
>0,7\end{array}$ & $\begin{array}{c}\text { Variância Média } \\
\text { Extraída (AVE) }\end{array}$ & $\mathbf{R}^{\mathbf{2}}$ \\
\hline Informação & 0,768 & 0,842 & 0,516 & \\
Intenção de Continuar Utilizando & 1,000 & 1,000 & 1,000 & 0,105 \\
Intenção de Recomendar & 1,000 & 1,000 & 1,000 & 0,152 \\
Interação do Serviço & 0,711 & 0,837 & 0,631 & \\
Usabilidade & 0,871 & 0,911 & 0,721 & \\
\hline
\end{tabular}

Fonte: Dados da pesquisa.

A teoria de mensuração especifica como os construtos são mensurados. A escala de mensuração da Modelagem de Equações Estruturais utilizada neste trabalho é reflexiva, assim, a direção de causalidade parte da variável latente para os indicadores (Hair et al., 2014). 
Figura 1 - Modelo proposto

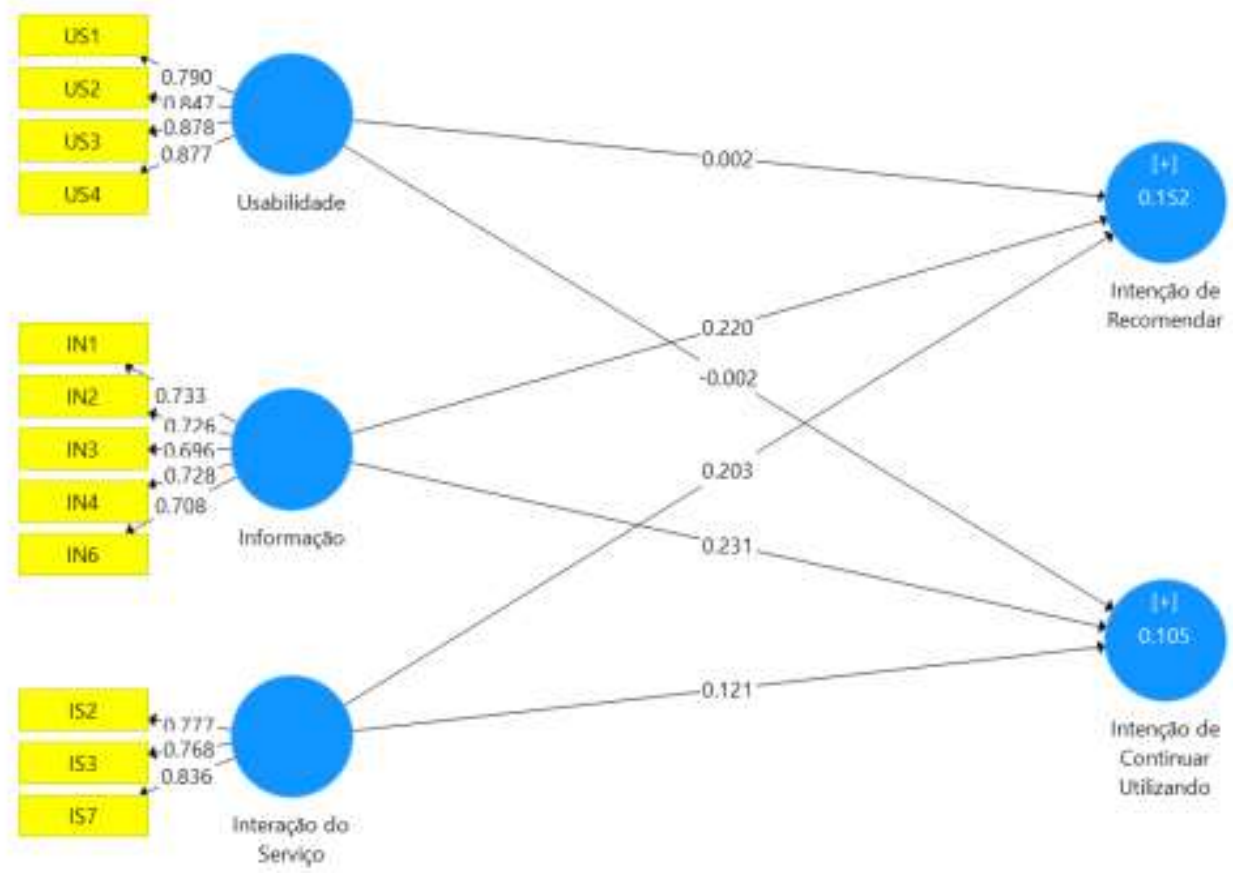

Fonte: Elaboração própria.

$\mathrm{Na}$ aplicação prática da Modelagem de Equações Estruturais para o modelo proposto, a abordagem sugere a avaliação dos modelos de mensuração individualmente, buscando verificar sua validade e consistência e, em seguida, realizar a abordagem do modelo estrutural. Assim, desenvolvem-se outras amostras compostas de elementos da amostra original e estimam-se os parâmetros do modelo (Hair et al., 2010).

O modelo proposto nesta pesquisa foi estimado com base na técnica bootstrapping, comparando a amostra original com as amostras geradas por essa técnica. Nesse sentido, foram geradas outras 500 amostras e realizado o teste $t$ Student. Estes valores são interpretados na Tabela 3 . 
Tabela 3 - Análise da significância dos caminhos

\begin{tabular}{|c|c|c|c|c|c|}
\hline Hypotheses and Paths & ( $\beta$ ) & Bootstrapping & SE & Statistic T & Sig. \\
\hline $\begin{array}{l}\text { H1a: Informação -> Intenção de } \\
\text { Continuar Utilizando }\end{array}$ & 0,231 & 0,237 & 0,066 & 3,506 & $*$ \\
\hline $\begin{array}{l}\text { H1b: Informação -> Intenção de } \\
\text { Recomendar }\end{array}$ & 0,220 & 0,226 & 0,068 & 3,236 & $* *$ \\
\hline $\begin{array}{l}\text { H2a: Interação do Serviço -> } \\
\text { Intenção de Continuar Utilizando }\end{array}$ & 0,121 & 0,125 & 0,064 & 1,900 & $* * *$ \\
\hline $\begin{array}{l}\text { H2b: Interação do Serviço -> } \\
\text { Intenção de Recomendar }\end{array}$ & 0,203 & 0,203 & 0,066 & 3,089 & $* *$ \\
\hline $\begin{array}{l}\text { H3a: Usabilidade -> Intenção de } \\
\text { Continuar Utilizando }\end{array}$ & $-0,002$ & $-0,056$ & 0,043 & 0,051 & N.S. \\
\hline $\begin{array}{l}\text { H3b: Usabilidade -> Intenção de } \\
\text { Recomendar }\end{array}$ & 0,002 & 0,055 & 0,041 & 0,046 & N.S. \\
\hline
\end{tabular}

Notas: $* \mathrm{p}<0,001, * * \mathrm{p}<0,05 * * * \mathrm{p}<0,10$.

Fonte: Dados da pesquisa.

Assim, os resultados mostram que as hipóteses $\mathrm{H} 1 \mathrm{a}$ e $\mathrm{H} 1 \mathrm{~b}$ indicam que o usuário demonstra preocupação com as informações ao utilizar os sites de serviços de turismo online. Tais preocupações estão relacionadas à precisão do site, confiabilidade, grau de relevância, nível de detalhe apropriado e o surgimento no momento exato da necessidade, alterando apenas o grau de significância. Quanto à H1a, a relação causal do caminho Informações e Intenção de Continuar Utilizando com $\beta=0,261$ foi significativa, apresentando o primeiro maior teste $\mathrm{t}=3,506$. $\mathrm{Na} \mathrm{H} 1 \mathrm{~b}$, houve a relação causal do caminho Informações e Intenção de Recomendação, $\operatorname{com} \beta=0,220$ e teste $t=3,236$, a segunda maior entre todas as hipóteses.

Possivelmente, os entrevistados desta pesquisa são usuários que buscam informações sobre o local a visitar, necessitando de mais informações antes da viagem para planejar as atividades que realizarão em seus destinos, obtendo, assim, viagens mais independentes e gratuitas, sem a necessidade de obter as informações necessárias. As informações contidas se tornam muito importantes, pois, por sua qualidade, os usuários passam a ter confiança no site. A confiança é um fator essencial no comércio eletrônico, bem como a compreensão de seus fatores e resultados. Primeiro, seus drivers nos permitem conhecer a importância relativa dos aspectos que a influenciam. A compreensão dessas variáveis é essencial para o desenvolvimento de medidas de fortalecimento da confiança. Segundo, seus resultados nos permitem entender melhor a importância da confiança e sua influência no comportamento das compras online. Numerosos estudos tentaram examinar a confiança como determinante crítico das intenções do consumidor em comprar no comércio eletrônico (Hsu, Chuang \& Cheng-Se, 2014; Agag \& El-Masry, 2016). No entanto, pouca atenção foi dada à confiança nos sites de 
viagens online ou se a confiança teria algum efeito no comportamento de seus clientes (Ayeh, $\mathrm{Au}, \&$ Law, 2013b; Filieri, 2015).

É fundamental que os sites ofereçam, acima de tudo, informações precisas, pois o turismo é intangível, heterogêneo e, diferentemente de outros produtos tangíveis e homogêneos, não pode ser testado antes da compra. Portanto, qualquer falha pode fazer com que a venda não entre em vigor. Outro fator determinante, que diferencia as compras de comércio eletrônico das lojas de varejo tradicionais, é a facilidade de comparações de preços e produtos similares, facilitando a alteração do site. Além disso, os usuários demoram a pesquisar online e a procurar produtos e/ou serviços que tenham valor. É necessário que as informações sejam claras, objetivas e precisas para despertar a motivação do usuário para continuar navegando.

Em relação à $\mathrm{H} 2 \mathrm{a}$, a relação causal da via Interação de Serviço e Intenção de Continuar Utilizando, $\operatorname{com} \beta=0,121$ e teste $t=1,900$, indicou baixa significância. Isso indica que o usuário se preocupa menos com a segurança e a entrega do produto/serviço, de acordo com o que foi contratado.

Quanto à H2b, a relação causal do Caminho de Interação de Serviço e Intenção de Recomendação teve $\beta=0,203$ e teste $t=3,089$, o terceiro maior entre todas as hipóteses. Isso indica que o usuário expressa preocupação com a segurança e a entrega do produto/serviço, de acordo com o contratado, antes de poder recomendá-lo a outros, ao contrário do resultado da intenção de continuar o uso.

Os entrevistados desta pesquisa, possivelmente, fazem parte dos denominados novos consumidores de turismo online. Esses consumidores são cada vez mais sofisticados e menos interessados em optar por pacotes turísticos padronizados, o que incentiva o turismo personalizado (Buhalis \& Law, 2008). Esses consumidores também são mais exigentes e buscam uma interação direta com o fornecedor, a fim de satisfazer seus desejos e expectativas específicos. Os usuários desse setor têm uma ampla variedade de ferramentas para organizar suas viagens, como agências de viagens online, mecanismos de pesquisa, redes sociais, portais, sites de comparação de preços, sites de compras coletivas, fornecedores individuais e sites intermediários. Todas essas ferramentas permitem as melhores interações, adequadas aos consumidores (Buhalis, 1998; Kim, Chung \& Lee, 2011; Amaro \& Duarte, 2015).

A disponibilidade das informações do produto em um ambiente virtual e a descrição didática de todas as etapas da compra são fatores que contribuem para a confiança do 
consumidor e para a descrição precisa de um produto/serviço. Isso ocorre porque compradores sabem exatamente o que e quando receberão (Wolfinbarger \& Gilly, 2003).

Como observado, a segurança ainda se apresenta como um fator de preocupação para os usuários, devido ao aumento de fraudes na rede, à impossibilidade de experimentar os produtos e à falta de garantias. Afinal, nas compras no comércio eletrônico, é necessário fornecer informações, como detalhes do cartão de crédito, endereço, telefone e data de nascimento e, geralmente, o produto/serviço não é adquirido conforme o esperado. No caso do turismo, também não há possibilidade de retorno. No entanto, em geral, atualmente existe um melhor conhecimento dos fornecedores, medidas de segurança reforçadas e, cada vez mais, sofisticadas estratégias, não influenciando negativamente a intenção do consumidor de continuar comprando produtos e serviços personalizados (Gretzel, Hwang, \& Fesenmaier, 2012).

Tanto a $\mathrm{H} 3 \mathrm{a}$ quanto a $\mathrm{H} 3 \mathrm{~b}$ indicam que o usuário não mostra preocupações com a facilidade de uso, operação, interação ou navegação do site. Esses itens não influenciam sua intenção de recomendar ou a continuidade do uso. Em relação à $\mathrm{H} 3 \mathrm{a}$, a relação causal do caminho Usabilidade e Intenção de Continuar Utilizando apresentam um caminho, com $\beta=$ .002 e teste $\mathrm{t}=0,051$ e em H3b, e há relação causal do caminho Usabilidade e Intenção de Recomendar, $\operatorname{com} \beta=0,002$ e teste $\mathrm{t}=0,046$.

Os participantes da pesquisa não demonstraram preocupação com a usabilidade, possivelmente devido ao contato diário com a internet e à capacidade de navegar pelos sites. No entanto, os usuários podem não representar o público em geral, que acessa sites de serviços de turismo online. Há empresas preocupadas com a usabilidade, pois descobriram que perderam dinheiro em acessos em que os usuários não conseguiam concluir com êxito seus objetivos, reduzindo a produtividade do usuário e aumentando o estresse e a insatisfação.

As principais falhas das páginas de produtos são: a) falta de destaque para as informações relevantes; b) falta de descrição do produto; c) falta de conquista (porque se concentram apenas na ação final de compra); d) uso de imagens que não ajudam a vender imagens que não mostram os detalhes dos produtos; e) uso de texto de difícil leitura (fonte pequena ou texto de baixo contraste ou informações importantes ausentes para decisão de compra); f) navegação que não promove a compra, com o uso de filtros que cobrem os produtos; g) desconsideração da descrição do produto, com informações incompletas ou incorretas, erros de ortografia ou digitação ou uso excessivo de termos técnicos; e h) falta de destaque do botão "comprar", entre outros. Nesse sentido, para aumentar as chances de 
compras concluídas, deve-se priorizar a página relevante para o consumidor, facilitando a visualização dos caminhos de interesse do usuário, investindo-se em imagens de qualidade e no destaque do botão de compra, com foco na descrição do produto, para que o site seja confiável.

Tabela 4 - Análise da significância dos caminhos (comparativo entre Alta Experiência e Baixa Experiência)

\begin{tabular}{|c|c|c|c|c|c|c|c|c|c|c|}
\hline \multirow{2}{*}{ Hypotheses and Paths } & \multicolumn{2}{|c|}{$(\beta)$} & \multicolumn{2}{|c|}{ Bootstrapping } & \multicolumn{2}{|c|}{ SE } & \multicolumn{2}{|c|}{ Statistic T } & \multicolumn{2}{|c|}{$P$ values } \\
\hline & Alta & Baixa & Alta & Baixa & Alta & Baixa & Alta & Baixa & Alta & Baixa \\
\hline $\begin{array}{l}\text { H1a: Informação -> Intenção de } \\
\text { Continuar Utilizando }\end{array}$ & 0,113 & 0,347 & 0,146 & 0,353 & 0,073 & 0,095 & 1,542 & 3,662 & 0,124 & 0,000 \\
\hline $\begin{array}{l}\text { H1b: Informação -> Intenção de } \\
\text { Recomendar }\end{array}$ & 0,120 & 0,291 & 0,154 & 0,303 & 0,087 & 0,094 & 1,375 & 3,083 & 0,170 & 0,002 \\
\hline $\begin{array}{l}\text { H2a: Interação do Serviço -> } \\
\text { Intenção de Continuar Utilizando }\end{array}$ & 0,077 & 0,133 & 0,101 & 0,134 & 0,068 & 0,076 & 1,138 & 1,750 & 0,256 & 0,081 \\
\hline $\begin{array}{l}\text { H2b: Interação do Serviço -> } \\
\text { Intenção de Recomendar }\end{array}$ & 0,148 & 0,213 & 0,152 & 0,211 & 0,078 & 0,087 & 1,893 & 2,446 & 0,059 & 0,015 \\
\hline $\begin{array}{l}\text { H3a: Usabilidade -> Intenção de } \\
\text { Continuar Utilizando }\end{array}$ & 0,042 & $-0,058$ & 0,074 & $-0,096$ & 0,057 & 0,068 & 0,736 & 0,857 & 0,462 & 0,392 \\
\hline $\begin{array}{l}\text { H3b: Usabilidade -> Intenção de } \\
\text { Recomendar }\end{array}$ & $-0,021$ & 0,004 & $-0,064$ & 0,079 & 0,047 & 0,061 & 0,442 & 0,069 & 0,658 & 0,945 \\
\hline
\end{tabular}

Fonte: Dados da pesquisa.

Ao comparar os grupos da pesquisa, conforme a Tabela 4, observa-se que o grupo denominado Alta Experiência apresenta algum grau de significância na hipótese $\mathrm{H} 2 \mathrm{~b}$, embora esse suporte seja baixo ( $p<0,1 \mathrm{t}=1,893$ ) e sem significância nas outras hipóteses. Observa-se que nesse grupo há um equilíbrio entre os entrevistados que compram serviço de turismo online entre jovens até 25 anos $(19 \%, \mathrm{n}=83)$ e idosos $(18,08 \%, \mathrm{n}=79)$.

O usuário do grupo Alta Experiência negligencia detalhes na navegação dos sites de comércio eletrônico dos serviços de turismo, pois encontra o mesmo design em outros sites com os quais eles têm contato no dia a dia. Portanto, os consumidores aderem à precisão, clareza e detalhes das informações contidas nos sites. Eles procuram sites que ofereçam serviços com boa reputação, segurança, seriedade e que estejam em conformidade com a entrega do produto/serviço que pretendem. Mas, acima de tudo, esses usuários querem que a empresa por trás do site entenda suas reais necessidades e atenda às suas expectativas.

O grupo denominado Baixa Experiência apresentou alto grau de significância na hipótese H1a ( $<<0,001 \mathrm{t}=3,662)$, seguida pela H1b ( $\mathrm{p}<0,05 \mathrm{t}=3,083), \mathrm{H} 2 \mathrm{~b}(\mathrm{p}<0,05 \mathrm{t}=$ 2,446) e H2a $\mathrm{p}<0,10 \mathrm{t}=1,75)$. Isso mostra que, para o perfil da amostra observada, composta majoritariamente por jovens de até 25 anos $(52,17 \% \mathrm{n}=228)$, é evidente que, apesar da 
prática predominante em baixa frequência de utilização do serviço de turismo online (30,22 \% $n=132)$, esse perfil tem uma alta predisposição para compra $(21,29 \% n=93)$. Nesse caso, os serviços de "recompra", sejam em sites de companhias aéreas, hotéis, serviços de entretenimento, ou diretamente de agências de serviços online, por exemplo, têm uma alta taxa de compra $(16,48 \% \mathrm{n}=72)$.

A responsabilidade da compra é compartilhada com parentes dos usuários, que executam o pagamento dos serviços. Nesse sentido, nem todos os serviços de turismo online possuem o mesmo sistema de pagamento (por exemplo, débito, número de vezes em crédito, passagem, entre outros). Assim, as famílias auxiliam nos custos, selecionando, por conveniência, a opção de pagamento mais adequada ao orçamento familiar. Eles costumam optar pelo sistema tradicional de venda em agências físicas. Neste estudo, considerando a amostra total, os valores de $\mathrm{R}^{2}$ dos construtos Intenção de continuar usando $(0,105)$ e Intenção de recomendar $(0,152)$ demonstram que o modelo possui precisão e relação preditiva.

$\mathrm{Na}$ análise do $\mathrm{R}^{2}$, surgiu uma diferença significativa entre os grupos Baixa Experiência e Alta Experiência. O grupo Baixa Experiência mostra valores de $\mathrm{R}^{2}$ mais altos que os valores da amostra total dos construtos Intenção de Continuar Usando $(0,220)$ e Intenção de Recomendar $(0,167)$, enquanto o grupo Alta Experiência apresenta valores bem abaixo de $\mathrm{R}^{2}$ para os construtos Intenção de Continue usando $(0,050)$ e a intenção de recomendar $(.039)$. Assim, podemos dizer que o grupo Baixa Experiência representa o melhor modelo, pois apresenta o mais alto nível de precisão preditiva e o melhor cenário explicativo.

\section{Conclusões}

O modelo proposto neste trabalho foi desenvolvido para medir os fatores antecedentes de qualidade em sites que contribuem para a experiência em serviços de turismo online, principalmente, no que diz respeito à intenção de continuidade de uso e recomendação.

Nesse sentido, foi desenvolvido um modelo teórico que utilizou vários construtos: Usabilidade, Informação e Interação de Serviço, a partir do modelo original de Barnes e Vidgen (2002) e estendido por Ahmad e Khan (2017). Os construtos Intenção de continuar usando e Intenção de recomendar foram adaptados do trabalho de Reichheld e Markey (2012).

O estudo indica que, para quem utiliza o site com mais frequência, as variáveis consideradas (facilidade, informação, segurança) não afetam a lealdade e a recomendação. Entre os usuários menos frequentes, as informações são importantes e a segurança tem pouco efeito sobre a recomendação. 
O modelo foi considerado parcialmente válido, e o construto Usabilidade não apresentou valores significativos, pois não influencia a intenção de continuar usando ou a intenção de recomendar. Os usuários não expressaram preocupação com a facilidade de uso, operação, interação ou navegação em relação aos sites. Os resultados confirmaram que esses construtos têm grande poder explicativo sobre os fatores antecedentes de qualidade nos sites, os quais contribuem para a experiência em serviços de turismo online na intenção de uso e recomendação.

A amostra, composta principalmente por jovens, consome, há muito tempo, produtos e serviços na Web. Nesse contexto, a segurança de um site já é uma condição mínima entendida como incorporada e a mesma especulação pode ser feita em relação à usabilidade percebida. A relação causal entre informação e intenção de continuar usando apresentou o $\beta$ mais alto $(0,223)$, confirmando o conceito de que a informação é necessária para a continuidade do uso de um serviço de turismo online. Entre as hipóteses válidas, a primeira apresentou um menor $\beta$ positivo $(0,121)$ na relação causal entre os construtos Interação de Serviço e Intenção de Continuar Utilizando. Uma explicação para esse $\beta$ mais baixo pode ser a suposição de que a segurança e a entrega dos produtos/serviços são pré-requisitos assumidos para a existência do site, para que os usuários não se importem tanto com esses itens de interação dos serviços.

Com este estudo, concluiu-se que algumas dimensões da qualidade da informação são mais importantes que outras para os usuários, como precisão, confiabilidade, relevância, nível adequado de detalhes e tempo. Quanto maior a percepção da qualidade das informações oferecidas, maior a confiança percebida. Além da qualidade das informações, a segurança percebida também contribui para maior confiança (Escobar-Rodríguez \& Carvajal-Trujillo, 2014, Kim \& John, 2008 e 2011).

Se um site de serviço de turismo online não oferecer informações completas e precisas, os consumidores poderão avaliar que não é adequado para concluir uma compra. Assim, as informações fornecidas pelo site devem ser precisas, claras, oportunas e suficientes em termos de profundidade de conteúdo, descrevendo as características do produto de viagem de forma clara e sem termos técnicos. Para aumentar a percepção do consumidor sobre a pontualidade e a precisão das informações, o site de viagens pode incluir um carimbo de data/hora para as informações (Kuan, Bock. \& Vathanophas, 2008). 


\subsection{Recomendações de gerenciamento}

Tanto o arcabouço teórico quanto os resultados da pesquisa destacam o papel do comércio eletrônico diante das novas tendências, que vêm modificando os serviços de turismo online. As transações online representam um novo estágio para a indústria do turismo, que está trabalhando para desenvolver as melhores práticas de negócios (Kim, Chung, \& Lee, 2011). Cada vez mais, os usuários buscam maior comodidade, otimização do tempo e melhores opções de produtos e ou serviços. As empresas devem se adaptar à nova realidade, evitando perder espaço no mercado em longo prazo e atendendo aos usuários que são influenciados pela velocidade das informações e mais conectados às manifestações nas redes sociais, blogs e notícias online.

As empresas de serviços de turismo online devem ouvir os desejos dos usuários, para orientarem as estratégias para aumentar seu desempenho. É essencial que, nesse processo, eles continuem a garantir a privacidade dos dados pessoais de seus clientes, por meio de soluções de segurança tecnológica, mantendo a confiança do usuário. Embora a usabilidade não tenha sido significativa neste estudo, ela pode ser usada como uma maneira de obter vantagem competitiva. O investimento no site é um fator que desempenha um papel relevante e que contribui para a segurança e privacidade percebidas (Ray, Ow, \& Kim; 2011). A usabilidade é um determinante crítico do sucesso de um site, quando o sucesso é medido pela satisfação e pela probabilidade do usuário voltar a usar o serviço (Agarwal \& Venkatesh, 2002).

As empresas tradicionais, que possuem apenas lojas físicas, devem otimizar o processo de adaptação a esse novo modelo de negócios, o comércio eletrônico, para que possam permanecer em suas posições no mercado ou manter um melhor posicionamento. A presença online da empresa mantém maior visibilidade de seus negócios, favorecendo a atração de mais consumidores, ampliando o atendimento virtual e estreitando o relacionamento com os usuários. Cada vez mais, o comprador passa por vários canais e pontos de contato, até tomar uma decisão. Omnichannel é um conceito que sustenta que todas as plataformas de contato e vendas devem estar disponíveis ao consumidor de forma integrada (Zhang et al., 2014).

As empresas devem investir, além do comércio eletrônico, no m-commerce, ou seja, em plataformas compatíveis com dispositivos portáteis, como smartphones, tablets e laptops, à medida que seu uso e demandas aumentam constantemente, com uma tendência de evolução contínua (Turner-McGrievy \& Tate, 2014). Afinal, geralmente, os usuários de serviços de turismo online, enquanto viajam, levam consigo dispositivos portáteis, pois servem como 
localizadores ou mesmo como guias turísticos e auxiliam nas transações bancárias. Assim, o viajante também poderia, durante a viagem, procurar acomodações, alugar um carro ou reservar um voo, por exemplo (Hew et al., 2016). O smartphone faz parte da vida cotidiana, incluindo viagens, que podem ser consideradas uma etapa especial no uso da tecnologia móvel na vida cotidiana, uma vez que o uso dessa tecnologia é moldado pela experiência do turismo e não o contrário (Wang, Xiang, \& Fesenmaier, 2014).

Os serviços de turismo online não se restringem apenas à pré-viagem, que foi o objetivo deste estudo. Esses serviços também podem cobrir as etapas durante após a viagem. Além disso, é possível ampliar o alcance de usuários e/ou consumidores por meio da tecnologia de sites interativos, sistemas de pedidos interativos, plataformas móveis interativas e viagens virtuais, entre outras coisas (Neuhofer, Buhalis, \& Ladkin, 2014).

Finalmente, o comércio eletrônico e os sites são ferramentas essenciais para a sustentabilidade das empresas em termos de redução de custos, proximidade e marketing direto com o usuário ou cliente. Em um mundo altamente competitivo e globalizado, o acesso a informações e conveniência nos serviços pressupõe um melhor uso dos recursos e um retorno financeiro mais atraente para as empresas.

A limitação inicial deste estudo pode ter sido a aplicação da escala WEBQUAL 4.0, pois não apresentou significância no construto usabilidade. Pode ser necessário atualizar a escala para o uso de novas tecnologias e sistemas de informação. Apesar disso, houve esforços para alcançar a usabilidade e o design, a qualidade da informação e a qualidade da interação do serviço (segurança e empatia). Nesse sentido, este estudo tentou fazer uma nova análise do modelo original. Esperamos ter contribuído com a literatura, adaptando dois modelos teóricos em um único modelo mais abrangente que os originais. Além disso, o modelo foi testado em momento no qual as plataformas digitais eram mais conhecidas pelos consumidores, quando comparado ao aplicativo realizado por Reichheld e Markey (2012).

Outra limitação deste estudo se refere ao fato de que o comportamento de compra eletrônica dos viajantes foi medido de uma perspectiva geral, independentemente do tipo de turismo, produto ou serviço adquirido. Os tipos de produto de viagem podem modificar o comportamento de compra eletrônica dos viajantes, porque o nível de risco percebido depende do custo do produto e do nível de tangibilidade (Hernandez, Jimenez, \& Martin, 2009).

Portanto, sugere-se, para pesquisas futuras, que fatores psicológicos (por exemplo, emoções e motivações) ou fatores sociais sejam explorados (normas subjetivas fazem parte dos modelos de uso de plataformas eletrônicas há algum tempo). É importante compreender 
esta agenda de pesquisa, além dos fatores antecedentes da intenção de usar/usar a recomendação, e os gatilhos mentais que explicam esses antecedentes. Além disso, com base nos resultados do presente estudo, uma compreensão adicional do papel da segurança e usabilidade percebidas pelo consumidor, principalmente por meio da identificação da (possível) moderação do entrevistado, pode lançar luz sobre o fenômeno identificado.

\section{References}

Agag, G. M., \& El-Masry, A. A. (2016). Why Do Consumers Trust Online Travel Websites? Drivers and Outcomes of Consumer Trust toward Online Travel Websites. Journal of Travel Research, 56(3), 347-369.

Agarwal, Ritu, and Viswanath Venkatesh. (2002). “Assessing a Firm's Web Presence: A Heuristic Evaluation Procedure for the Measurement of Usability." Information Systems Research, 13 (2), 168-86.

Ahmad, A., \& Khan, M. N., (2015a). Mapping online buyer behavior: A critical review of empirical studies. Pacific Business Review International, 8 (2), 37-48.

Ahmad, A., Rahman, O. \& Khan, M. N., (2016). Consumer's perception of website service quality: An empirical study. Journal of Internet Commerce, 15 (2), 125-41.

Ahmad, A., \& Khan M. N. (2017). Developing a Website Service Quality Scale: A Confirmatory Factor Analytic Approach. Journal of Internet Commerce, 16:1, 104-126.

Ahn, T., Ryu, S., \& Han, I. (2007). The impact of Web quality and playfulness on user acceptance of online retailing. Information and Management, 44, 263-275.

Amaro, S., \& Duarte, P. (2015). An integrative model of consumers' intentions to purchase travel online. Tourism Management, 46, 64-79.

Aye, J.K. \& Law, R. (2013b). "Predicting the Intention to Use Consumer Generated Media for Travel Planning." Tourism Management, 35:132-43.

Barnes, S. J. \& Vidgen, R. T. (2002). An integrative approach to the assessment of eommerce quality. Journal of Electronic Commerce Research, 3 (3),114-27.

Brasil, Ministério do Turismo (2018). Intenção de Viagem. Sondagem do Consumidor. Fundação Getulio Vargas. São Paulo.

Buhalis, D. (1998). Strategic use of information technologies in the tourism industry. Tourism Management, 19 (5), 409-421.

Buhalis, D. \& Law, R. (2008). Progress in information technology and tourism management: 20 years on and 10 years after the Internet. Tourism Management, 29(4), 609-623.

Cárdenas-García, P. J., Sánchez-Rivero, M. \& Pulido-Fernández, J. I. (2015). Does Tourism Growth Influence Economic Development? Journal of Travel Research, 54 (2), 206-21.

Chin W.W. (1998). The Partial Least Squares Approach for Structural Equation Modeling. "In GA Marcoulides (ed.), Modern Methods for Business Research, 295-336. Lawrence Erlbaum Associates, London.

Chu, R. (2001). What online Hong Kong travelers look for on airline/travel websites? International Journal of Hospitality Management, 20, 95-100.

Conger, S., Hefley, B., Galup,S. \& Dattero, R. (2012). Service Quality Measurement: Past and Future. Working Papers on Information System.

Cronin Jr., J. J. (2003). Looking back to see forward in services marketing: Some ideas to consider. Managing Service Quality: An International Journal, 13 (5), 332-37.

DeLone, H. W., \& McLean, R. E. (2003). The DeLone and McLean model of information systems success: A ten-year update. Journal of Management Information Systems, 19, 9-30. 
Deng, L., \& Poole, M. S. (2012). Aesthetic design of e-commerce web pages-Webpage complexity, order and preference. Electronic Commerce Research and Applications, 11 (4), 420-40.

Do Valle, P. O., \& Assaker, G. (2015). Using Partial Least Squares Structural Equation Modeling in Tourism Research. Journal of Travel Research, 55(6), 695-708.

Dziuban, C. D., \& Shirlkey, E. C. (1974). When is a correlation matrix appropriate for factor analysis? Some decision rules. Psychological Bulletin, 81 (6), 358-361.

Escobar-Rodíguez, T. \& Carvajal-Trujillo, E. (2014). Online purchasing tickets for low cost carriers: an application of the unified theory of acceptance and use of technology (UTAUT) model. Tourism Management, 43 (August), 70-88.

Ferguson, G., Megehee, C. M., \& Woodside, A. G. (2017). How Recipes of National Cultural Values, Wealth, Economic Inequality, and Religiosity Explain Consumer Tipping Behavior: An Abstract. In Creating Marketing Magic and Innovative Future Marketing Trends (pp. 1337-1337). Springer, Cham.

Filieri, R. (2015). "Why Do Travelers Trust TripAdvisor? Antecedents of Trust towards Consumer-Generated Media and Its Influence on Recommendation Adoption and Word of Mouth." Tourism Management, 51:174-85.

Fornell, C. \& Larcker, D. F. (1981). Evaluating structural equation models with unobservable variables and measurement error. Journal of marketing research, Vol. 18, No. 1 (Feb., 1981), pp. 39-50.

Gretzel, U., Y. H. Hwang, and D. R. Fesenmaier. (2012). "Informing Destination Recommender Systems Design and Evaluation through Quantitative Research." International Journal of Culture, Tourism and Hospitality Research, 6 (4): 2-2.

Hair, J. F., Black, W. C., Babin, B. J. \& Anderson, R. E. (2010). Multivariate Data Analysis: A Global Perspective, New Jersey, Pearson Prentice Hall.

Hair, J.F.; Hult, T.M.; Ringle, C.M. \& Sarstedt, M. (2014). A Primer on Partial Least Squares Structural Equation Modeling (PLS-SEM). SAGE. Los Angeles.

Hernandez, B., Jimenez, J., \& Martin, M. J. (2009). The impact of self-efficacy, ease of use and usefulness on e-purchasing: An analysis of experienced shoppers. Interacting with Computers, 21, 146-156.

Hew, J. J., Lee, V. H., Leong, L. Y., Hew, T.S. \& Ooi, K. B. (2016). The dawning of mobile tourism: what contributes to its system success? International J. Mobile Communications, 14 (2), 170-201.

Ho, C. I., \& Lee, L. Y. (2007). The development of an e-travel service quality scale. Tourism Management, 28, 1434-1449.

Hsu, Meng-Hsiang, Chuang Li-Wen, and Hsu Cheng-Se. 2014. "Understanding Online Shopping Intention: The Roles of Four Types of Trust and Their Antecedents." Internet Research, 24 (3): 332-52.

Jain, S. K. \& Gupta, G. (2004). Measuring service quality: SERVQUAL versus SERVPERF scales. Vikalpa, 23-35.

Kvålseth, T. O. (1985). Cautionary note about R ${ }^{2}$. The American Statistician, 39(4), 279-285.

Kim, H., \& John, D. R. (2008). Consumer response to brand extensions: construal level as a moderator of the importance of perceived fit. Journal of Consumer Psychology, 18 (2), 116-126.

Kim, M. J., Chung, N., \& Lee, C. K. (2011). The effect of perceived trust on electronic commerce: shopping online for tourism products and services in South Korea. Tourism Management, 32 (2), 256-265.

Kourtit, K., Nijkamp, P., van Leeuwen, E.S. \& Bruinsma, F. (2011). Evaluation of cyber-tools in cultural tourism, International Journal of Sustainable Development. 
Kuan, H. H., Bock, G.W., \& Vathanophas, V. (2008). Comparing the effects of website quality on customer initial purchase and continued purchase at ecommerce websites. Behaviour \& Information Technology, 27(1), 3-16.

Lee, T. H. (2013). Influence analysis of community resident support for sustainable tourism development. Tourism Management, 34, 1-10.

Lee, Y., \& Kozar, A. K. (2006). Investigating the effect of website quality on ebusiness success: An analytic hierarchy process (AHP) approach. Decision Support Systems, 42, 1383-1401.

Levin, J., Fox, J. A., \& Forde, D. R. (2013). Elementary Statistic in Social Research. Pearson, 12 edition (June 23).

Lin, S. P., Chan, Y. H., \& Tsai, M. C. (2009). A transformation function corresponding to IPA and gap analysis. Total Quality Management \& Business Excellence, 20, 829-846.

Madu, C. N., \& Madu, A. A. (2002). Dimensions of e-quality. International Journal of Quality and Reliability Management, 19 (3), 246-258.

Malhotra, N. K. (2014). Essencials of Marketing Research: A Hands-on Orientation. Prentice Hall, 1 Edition, January 20.

Mohd-Any, A. A., Winklhofer, H., \& Ennew, C. (2014). Measuring Users' Value Experience on a Travel Website (e-Value). Journal of Travel Research, 54(4), 496-510.

Munar, A. M., \& J. Jacobsen, J. K. S. (2013). "Trust and Involvement in Tourism Social Media and Web-Based Travel Information Sources." Scandinavian Journal of Hospitality and Tourism, 13 (1): 1-19.

Munar, A. M., \& Jacobsen, J. K. S. (2014). Motivations for sharing tourism experiences through social media. Tourism Management, 43, 46-54.

Neuhofer, B., Buhalis, D. \& Ladkin, A. (2014). A typology enhanced experiences, International Journal of Tourism Research, 16, 340-350.

Parasuraman, A., Zeithaml, V. A. \& Berry, L. L. (1985). A conceptual model of service quality and its implications for future research. The Journal of Marketing, 49 (4), 41-50.

Park, Y. J., Campbell, S. W., \& Kwak, N. (2012). Affect, cognition and reward: Predictors of privacy online. Computers in Human Behavior, 28(3), 1019-1027.

Pett, M., Lackey, N. \& Sullivan, J. (2003). Making sense of factor analysis. Thousand Oaks: Sage Publications, Inc.

Ray, S., Ow, T., \& Kim, S. S. (2011). Security assurance: how online service providers can influence security control perceptions and gain trust. Decision Sciences, 42 (2), 391-412.

Reichheld, F. F. \& Markey, R. (2012). The Ultimate Question 2.0. Harvard Business Review Press.

Schmidt, S., Cantallops, A. S., \& Santos, P. C. (2008). The characteristics of hotel websites and their implications for website effectiveness. International Journal of Hospitality Management, 27, 504-516.

Simon, H. A. (2001). Science seeks parsimony, not simplicity: Searching for pattern in phenomena. Simplicity, inference and modelling: Keeping it sophisticatedly simple, 32-72

Turner-McGrievy, G.M. \& Tate, D.F. (2014). Are we sure that mobile health is really mobile? An examination of mobile device uses during two remotely-delivered weight loss interventions. International Journal of Medical Informatics, 83 (5), 313-319.

UNCTAD (2017). Information Economy Report 2017. Digitalization, Trade and Development.

World Tourism Organization (2018), UNWTO Tourism Highlights, 2018. Edition, UNWTO, Madrid.

Wang, D., Xiang, Z., \& Fesenmaier, D. R. (2014). Smartphone Use in Everyday Life and Travel. Journal of Travel Research, 55(1), 52-63. 
Werthner, H. \& Ricci, F. (2004) E-commerce and tourism. Communications of the ACM, 47 (12), 101-105.

Wolfinbarger, M. \& Gilly, M. C. (2003). eTailQ: Dimensionalizing, measuring and predicting etail quality. Journal of Retailing 79, 183-198.

WTTC (2018). Economic Impact 2017 Brazil. Travel and Tourism.

Yoo, B., \& Donthu, N. (2001). Developing a Scale to Measure the Perceived Quality of an Internet Shopping Site (SITEQUAL). Quarterly Journal of Electronic Commerce.

Zeithaml, V. A., Parasuraman, A. \& Malhotra, A. (2000). Conceptual framework for understanding e-service quality: Implications for future research and managerial practice. Working Paper no. 00-115. Marketing Science Institute, Cambridge, MA.

Zeithaml, V.A., Parasuraman, A. \& Malhotra, A (2002). Service quality delivery through web sites: A critical review of extant knowledge. Journal of the Academy of Marketing Science, 30, (4), 362-375.

Zhang, H., Fu, X., Cai, L. A., \& Lu, L. (2014). Destination image and tourist loyalty: A metaanalysis. Tourism Management, 40, 213-223. 
Apêndice A - Apresentação dos construtos, indicadores, assertivas e referências do modelo

\begin{tabular}{|c|c|c|c|}
\hline Construtos & Indicadores & Descrição das Assertivas & Referências \\
\hline \multirow{13}{*}{ Usabilidade } & US1 & $\begin{array}{l}\text { Eu acho fácil aprender como operar o site de serviço online de } \\
\text { turismo que mais uso. }\end{array}$ & \multirow{30}{*}{$\begin{array}{c}\text { Ahmad e } \\
\text { Khan (2017) }\end{array}$} \\
\hline & & É muito fácil interagir com o site de serviço online de turismo & \\
\hline & US2 & que mais uso. & \\
\hline & & Eu acho fácil navegar no site de serviço online de turismo que & \\
\hline & US3 & mais uso. & \\
\hline & & Eu acho fácil usar o site de serviço online de turismo que mais & \\
\hline & US4 & uso. & \\
\hline & & O site de serviço online de turismo que mais uso tem aparência & \\
\hline & US5 & atraente. & \\
\hline & & O site de serviço online de turismo que mais uso tem um & \\
\hline & US6 & design apropriado. & \\
\hline & US7 & $\begin{array}{l}\text { O site de serviço online de turismo que mais uso parece } \\
\text { competente. }\end{array}$ & \\
\hline & US8 & $\begin{array}{l}\text { O site de serviço online de turismo que mais uso cria uma } \\
\text { experiência positiva para mim. }\end{array}$ & \\
\hline \multirow{9}{*}{ Informação } & IN1 & $\begin{array}{l}\text { As informações do site de serviço online de turismo que mais } \\
\text { uso são precisas. }\end{array}$ & \\
\hline & IN2 & $\begin{array}{l}\text { As informações do site de serviço online de turismo que mais } \\
\text { uso são confiáveis. }\end{array}$ & \\
\hline & IN3 & $\begin{array}{l}\text { O site de serviço online de turismo que mais uso fornece } \\
\text { informações no momento em que preciso. }\end{array}$ & \\
\hline & IN4 & $\begin{array}{l}\text { As informações do site de serviço online de turismo que mais } \\
\text { uso são relevantes. }\end{array}$ & \\
\hline & & As informações do site de serviço online de turismo que mais & \\
\hline & IN5 & uso são fáceis de entender. & \\
\hline & & As informações do site de serviço online de turismo que mais & \\
\hline & IN6 & uso tem nível adequado de detalhes. & \\
\hline & IN7 & $\begin{array}{l}\text { As informações do site de serviço online de turismo que mais } \\
\text { uso tem formato apropriado. }\end{array}$ & \\
\hline \multirow{8}{*}{$\begin{array}{l}\text { Interação } \\
\text { do Serviço }\end{array}$} & IS1 & $\begin{array}{l}\text { O site de serviço online de turismo que mais uso tem ótima } \\
\text { reputação. }\end{array}$ & \\
\hline & IS2 & $\begin{array}{l}\text { Parece seguro concluir as transações no site de serviço online } \\
\text { de turismo que mais utilizo. }\end{array}$ & \\
\hline & & Minhas informações pessoais são mantidas em segurança no & \\
\hline & IS3 & site de serviço online de turismo que mais uso. & \\
\hline & IS4 & $\begin{array}{l}\text { Sinto que o site de serviço online de turismo foi personalizado } \\
\text { para meu uso. }\end{array}$ & \\
\hline & IS5 & $\begin{array}{l}\text { O site de serviço online de turismo que mais uso faz me sentir } \\
\text { em uma rede social. }\end{array}$ & \\
\hline & IS6 & $\begin{array}{l}\text { O site de serviço online de turismo que mais uso facilita muito } \\
\text { a comunicação com a empresa. }\end{array}$ & \\
\hline & IS7 & $\begin{array}{l}\text { Confio que os produtos/serviços do site de serviço online de } \\
\text { turismo que mais uso serão entregues conforme prometido. }\end{array}$ & \\
\hline \multicolumn{2}{|c|}{$\begin{array}{l}\text { Cont_utilizar } \\
\text { recomendar }\end{array}$} & $\begin{array}{l}\text { Pretensão de continuidade de uso do site. } \\
\text { Intenção de recomendar o site para um (a) amigo (a). }\end{array}$ & $\begin{array}{l}\text { Reichheld e } \\
\text { Markey } \\
(2012)\end{array}$ \\
\hline
\end{tabular}

Fonte: Elaboração própria. 